UNIVERSIDADE DE SÃO PAULO

FACULDADE DE FILOSOFIA, LETRAS E CIÊNCIAS HUMANAS

DEPARTAMENTO DE LETRAS CLÁSSICAS E VERNÁCULAS

PROGRAMA DE PÓS-GRADUAÇÃO EM LITERATURA

BRASILEIRA

\title{
A morte nas crônicas memorialísticas de Helena Silveira
}

Noelma Brocanelli

Dissertação apresentada ao Programa de Pós-Graduação em Literatura Brasileira da Faculdade de Filosofia, Letras e Ciências Humanas da Universidade de São Paulo, para a obtenção do título de Mestre em Letras.

Orientador: Prof. Dr. José Alcides Ribeiro 


\section{RESUMO}

Esta dissertação tem como objetivo principal o estudo das crônicas de memória de Helena Silveira contidas em sua obra Sombra Azul e Carneiro Branco. Publicada em 1960, trata-se de uma seleção de crônicas escolhidas em vida pela autora, que, inicialmente, foram publicadas na seção "Paisagem e memória" do jornal Folha da Manhã. A caracterização das crônicas tem como principal objetivo o reconhecimento de suas técnicas de composição, partindo da temática referente à morte. Esta análise permitirá discutir a relação entre os gêneros cronístico e memorialístico, resgatar a importância da produção literária de Helena Silveira e traçar um perfil de sua relação com a temática. Para isso, constará neste estudo um resgate histórico e conceitual sobre os gêneros cronístico e memorialístico, uma análise minuciosa de tais crônicas no tocante às técnicas de composição da autora, ao ponto de vista, à temática e à presença das crônicas no gênero memorialístico brasileiro.

Palavras-chave: Helena Silveira; Sombra Azul e Carneiro Branco; memória; memorialismo; crônica; ponto de vista; foco narrativo; morte. 


\section{ABSTRACT}

This paper aims to present the study about Helena Silveira's memory chronicles in her book Sombra Azul e Carneiro Branco. Released in 1960, the book is an author's selection of chronicles, which was previously published in the Folha da Manhã newspaper, inside the section "Paisagem da memória" (Memory's landscape, in verbal translation). The chronicles characterization has, as main purpose, the recognition of composing techniques starting from the death theme. This analysis allows the discuss about and between the chronicle and the memory text styles, as a rescue of the influence of Helena Silveira's literary work; and also allows a profile trace of her relation with the mentioned theme. This paper is a study about the historical and conceptual redemption of chronicle and memory text styles; it is a particular analysis of the chronicles of Sombra Azul e Carneiro Branco book concerning the author's composition techniques, her point of view, the selected theme, and the Brazilian chronicles written with the memorial text style.

Keywords: Helena Silveira; Sombra Azul e Carneiro Branco; memory; autobiographical writing; fictional writing; chronicle; point of view; narrative focus; death. 


\section{FOLHA DE APROVAÇÃO}

Noelma da Silva Brocanelli

A morte nas crônicas memorialísticas

de Helena Silveira

Dissertação apresentada à Faculdade de

Filosofia, Letras e Ciências Humanas da

Universidade de São Paulo para obtenção do título de Mestre.

Área de Concentração: Literatura

Brasileira

Aprovado em:

\section{Banca examinadora}

Prof. Dr.

Instituição:

Assinatura:

Prof. Dr.

Instituição:

Assinatura:

Prof. Dr.

Instituição:

Assinatura:

Prof. Dr.

Instituição:

Assinatura:

Prof. Dr.

Instituição:

Assinatura: 


\section{SUMÁRIO}

1 Introdução $\quad 07$

2. Os gêneros cronístico e memorialístico 12

2.1 Breve relato sobre a imprensa periódica 12

$\begin{array}{ll}\text { 2.2. Folhetim: a origem da crônica } & 18\end{array}$

2.3. A crônica 22

2.4 O gênero memorialístico 35

3 Fundamentação teórica 41

3.1 Foco narrativo ou ponto de vista 41

$\begin{array}{ll}\text { 3.1.1 Perspectiva } & 47\end{array}$

3.2 Tempo de narração $\quad 51$

3.2.1 Anacronias $\quad 52$

3.2.2 Tipologia da dimensão noticiosa das crônicas: tipologia da linguagem jornalística e cronística 55

4 Crônicas de memória: visões sobre a morte 58

4.1 Especificações do corpus $\quad 58$

$\begin{array}{ll}4.2 \text { Análise das crônicas } & 60\end{array}$

4.2.1 Crônica: A viagem e o beijo 62

4.2.1.1 Temática 62

4.2.1.2 Tipologia da linguagem jornalística e cronística 65

4.2.1.3 Foco narrativo $\quad 69$

$\begin{array}{ll}\text { 4.2.2 Crônica: Encontro com meu pai } & 73\end{array}$

$\begin{array}{ll}\text { 4.2.2.1 Temática } & 73\end{array}$

$\begin{array}{ll}\text { 4.2.2.2 Foco narrativo } & 76\end{array}$ 
4.2.2.3 Tipologia da linguagem jornalística e cronística

4.2.3 Crônica: O príncipe Sisido

4.2.3.1 Temática

4.2.3.2 Tipologia da linguagem jornalística e cronística

83

4.2.3.3 Articulação temporal da narrativa 87

4.2.3.4 Foco narrativo $\quad 89$

$\begin{array}{ll}\text { 4.2.4 Crônica: Geografia da morte } & 91\end{array}$

$\begin{array}{ll}\text { 4.2.4.1 Temática } & 91\end{array}$

4.2.4.2 Tipologia da linguagem jornalística e cronística 92

4.2.4.3 Articulação temporal da narrativa 92

4.2.4.4 Foco narrativo 95

5 Considerações finais $\quad 97$

5.1 As visões sobre a morte nas crônicas de Helena Silveira 97

6 Referências bibliográficas 100

$\begin{array}{ll}7 \text { Anexo A } & 106\end{array}$

8 Anexo B 115

9 Anexo C 117 


\section{INTRODUÇÃO}

Os séculos $\mathrm{XIX}$ e $\mathrm{XX}$ foram marcados por intensas transformações sociais e culturais no mundo. Revolução industrial, cultural e da comunicação fizeram desses séculos momentos ricos para o desenvolvimento da humanidade. Dentro dessa perspectiva, as artes, em especial a literatura, desenvolveram-se e singularizaram-se com a criação de novos gêneros.

Entre os gêneros que se enraizaram nas práticas literárias deste período está a crônica. Por ser um gênero que nasceu e ganhou força na efemeridade dos periódicos, ainda hoje é pouco estudado e valorizado. São poucos os autores que se destacaram unicamente por terem se doado à sua produção.

Um dos autores que se dedicaram à produção de crônicas durante quatro décadas foi Helena Silveira. Considerada uma escritora de estilo singular, Helena Silveira, por meio de suas crônicas, mostra exatamente como esse gênero é capaz de invadir os mais diversos meios de comunicação e de se adaptar a eles. Afinal, é um gênero que transitou (e transita) pelas folhas dos jornais, que chegou aos livros e que vem acompanhando, desde seu nascimento, a evolução dos meios de comunicação.

Figura atuante na imprensa e no meio literário do estado de São Paulo, Helena Silveira contribuiu durante anos com a seção "Paisagem e memória" do jornal Folha da Manhã (que deu origem à Folha de S.Paulo, juntamente com a Folha da Noite e a Folha da Tarde). Também escreveu contos e colaborou com outros jornais. Entre 1961 e 1963 exerceu o cargo de presidente da União Brasileira de Escritores. Foi crítica e redatora de TV e de rádio. Recebeu, entre outros, o Prêmio Roquete Pinto, instituído pela TV Record para os melhores profissionais. 
A obra que aqui será objeto de estudo é Sombra Azul e Carneiro Branco, uma reunião de crônicas de Helena publicadas originalmente na seção "Paisagem e memória". Após um estudo de tais crônicas de Helena Silveira, constatou-se que boa parte da obra é composta por crônicas memorialísticas. O gênero memorialístico ganhou força na literatura a partir da década de 1930 e invadiu diversos outros gêneros, como é o caso, aqui, da crônica. Desse modo, o foco dessa dissertação é o estudo das crônicas de memória de Helena Silveira.

Ainda que Helena Silveira tenha publicado crônicas de memórias por anos a fio nos periódicos, essa pesquisa ficará restrita à obra Sombra Azul e Carneiro Branco, pois se trata de sua primeira coletânea de crônicas reunidas pela própria autora.

Com o desenrolar dos estudos, constatou-se que, entre as diversas temáticas exploradas por Helena Silveira, o tema da morte é o mais recorrente. Com base nesse fator, decidiu-se focar a análise nas crônicas de memória cuja temática tenha a morte como referência.

Em "Os gêneros cronístico e memorialístico" foi feito um breve estudo sobre o desenvolvimento da imprensa periódica em que são citadas importantes personalidades que contribuíram com a disseminação da literatura nos periódicos. Foram consideradas importantes teorias críticas que versam sobre o gênero cronístico e artigos que observam suas peculiaridades e seu surgimento nos jornais.

Foi considerada a obra de Afrânio Coutinho, A Literatura no Brasil, que traz uma emaranhado de informações sobre a mescla dos gêneros literários e jornalísticos. Trata-se de uma referência no tocante aos estudos literários.

Considerou-se também a obra de Nelson Werneck Sodré, História da Imprensa no Brasil, com diversas informações para a compreensão da evolução da imprensa e da propagação da literatura nos periódicos. 
Neste capítulo também foram descritas as principais características de veiculação da seção Folhetim, espaço eu proporcionou a divulgação do gênero cronístico. Para este estudo foi considerada a obra de Marlyse Meyer, Folhetim. Uma obra que conta toda a história do nascimento da seção Folhetim e do romancefolhetim. Também foi considerado o estudo do professor José Alcides Ribeiro na obra Imprensa e ficção no século XIX para discorrer sobre as características do Folhetim.

Ainda nesse capítulo, também foi feito um breve levantamento a respeito dos principais aspectos do gênero memorialístico, além de observações no tocante à sua proximidade com o gênero cronístico. O objetivo desse capítulo é traçar os perfis de ambos os gêneros e mostrar como se misturam. Um estudo bastante consistente sobre o memorialismo no Brasil é a tese de doutorado de Afonso Henrique Fávero, chamada "Aspectos do Memorialismo Brasileiro". Alguns dos seus conceitos apontados por ele serão aqui mencionados pela relevância da caracterização do gênero memorialístico nesta dissertação.

A obra de Fávero analisa basicamente obras de Graciliano Ramos, Cyro dos Anjos e Pedro Nava, cujas concepções têm como foco o memorialismo. Apesar de Fávero tratar de romances, ele faz em seu trabalho um apanhado das principais características do gênero memorialístico que serão aqui retomadas com o intuito de relacioná-las ao gênero cronístico.

"Fundamentação teórica" versa sobre as teorias que tratam do foco narrativo, a temporalidade e às suas variações de perspectivas nas crônicas memorialísticas. Também são citadas aqui as principais características do gênero noticioso exploradas pela crônica, que complementará a análise. 
Para a concepção deste capítulo sobre a fundamentação teórica foram relevantes as teorias de Gérard Genette, Tzvetan Todorov, Teun A. van Dijk e considerações de Maria Lúcia Dal Farra.

A obra de Gérard Genette, Discurso da Narrativa, é um estudo sobre a obra de Proust $\grave{A}$ la Recherche du temps perdu, que questiona as várias possibilidades de se contar uma narrativa.

Os principais aspectos considerados nesta obra de Genette são os aspectos de ordenação, no sentido de percepção do sentido dos encadeamentos na narrativa; os aspectos de duração com o intuito de estabelecer ritmo à narrativa; os aspectos de freqüência no tocante à relação temporal entre a narrativa e a diegese; além do ponto de vista e a voz narrativa, que questionam a presença do foco narrativo.

A obra de Tzvetan Todorov considerada neste estudo chamasse Estruturalismo e poética que traz reflexões sobre as possíveis visões na narrativa, discutindo a atuação do narrador no processo discursivo da narrativa.

A obra de Maria Lúcia Dal Farra, O narrador ensimesmado, é formada com base nas obras de Genette e Todorov e traz reflexões sobre a presença do narrador e da escolha do foco narrativo, revelando uma possível manipulação do narrador.

A obra de Teun A. van Dick analisa as notícias como um determinado tipo de discursos de periódicos, comparando-os com outros tipos de discursos e evidenciando suas particularidades. Para isso, Van Dick faz uso de teorias ligadas à lingüística, à estilística e à retórica.

"Crônicas de memória: visões sobre a morte" aborda as principais técnicas de composição das crônicas de memória de Helena Silveira. Após análise minuciosa, constatou-se que a temática mais recorrente em suas crônicas é a morte. Diante desse aspecto, há como principais objetivos nesse capítulo, analisar a relação de Helena 
Silveira com esta temática por meio de caracterização detalhada das crônicas mais representativas que abordam tal temática. Os principais aspectos abordados foram a focalização, os aspectos noticiosos, os literários e as características estilísticas.

Para isso, foram selecionadas quatro de vinte crônicas, que tem a morte como temática. Para esta seleção foram consideradas crônicas memorialísticas, cuja temática fosse a morte, discutida por meio de diferentes aspectos, e sem caráter autobiográfico. As crônicas que foram objeto deste estudo constam no Anexo A. As outras dezesseis crônicas que também tem a morte como temática foram inseridas no Anexo C.

Com base nesta análise, pretende-se, ao final, demonstrar a relação da autora com a temática. 


\section{OS GÊNEROS CRONÍSTICO E MEMORIALÍSTICO}

\subsection{Breve relato sobre a imprensa periódica}

Segundo Coutinho (1971), as vozes da literatura no Brasil não correspondem à chegada da imprensa. Um longo percurso foi percorrido pelos jornais para que eles começassem a disseminar a literatura entre seus leitores.

Quando a imprensa chegou ao Brasil em 1808, surgiu, então, o primeiro jornal, chamado Gazeta do Rio de Janeiro. Foi um jornal totalmente direcionado aos fatos oficiais do Governo, pois era dirigido pelo próprio Governo, não publicava literatura.

Essa ausência de literatura nos jornais brasileiros causava estranheza aos visitantes estrangeiros que aqui chegavam. Coutinho (1971, p. 65) menciona o caso de Maria Graham, inglesa muito culta que em 1823, mencionava em seu Diário, durante visita ao Brasil, que "seria de incalculável valor que os novos autores, precisando de estímulo tivessem seus poemas postos em destaque" na imprensa.

Armitage $^{1}$ reflete sobre essa questão da ausência de literatura nos jornais brasileiros no início do século XIX:

[...] Na Europa, onde os meios de informação são numerosos e variados, a influência da imprensa periódica é sensível e confessada por todos; mas no Brasil, onde ainda não se alcançara um nível razoável na produção literária, e os jornais políticos representavam quase a única forma de abstenção de conhecimentos, a força das

1. ARMITAGE, John. The history of Brazil... Londres: 1836, II, p. 2. 
gazetas era ainda mais poderosa. (ARMITAGE, 1836, p. 2 apud COUTINHO, 1971, p. 67).

Percebe-se como a produção e a difusão literária eram escassas no Brasil, e foi assim durante todo o Primeiro Reinado, com os jornais a serviço do Império.

Um dos precursores da entrada da literatura nos periódicos foi Evaristo Ferreira da Veiga (1799-1837), livreiro e jornalista, que possuía um caráter moderado capaz de equilibrar a tradição e o novo. Em 1827, Evaristo da Veiga criou a Aurora Fluminense, jornal que renovou a expressão jornalística.

Já no Segundo Reinado, outro clima se estabelecera no Brasil, e a ordem da liberdade de imprensa se instalara, pois o país começara a ser mais reconhecido no exterior.

Uma das figuras mais importantes do jornalismo no período do Segundo Reinado foi Francisco Otaviano de Almeida Rosa (1825-1889). Segundo Coutinho (1971), Francisco Otaviano, jornalista, político e poeta, muito influente entre os intelectuais. Em colaboração ao jornal O Correio Mercantil, do Rio de Janeiro, ele criou o principal periódico propagador das criações literárias e artísticas da época.

Cascudo $^{2}$ afirma:

Francisco Otaviano realizava o mais completo tipo de jornalista político que tivemos no Segundo Império. Dele era a claridade meridiana dos períodos, a simplicidade da frase que não significava pobreza, mas um milagre de bom gosto sóbrio e preciso num ambiente de estilo foguete de festa e bombo de arraial. (CASCUDO, 1938, P. 254 apud COUTINHO, 1971, p. 76).

2. CASCUDO, Luís da Câmara. O marquês de Olinda e seu tempo. São Paulo: Cia. Editora Nacional. 1938, p. 254. 
É nítida a importância de Otaviano, que não pára por aí. De acordo com Coutinho (1971), Otaviano foi o precursor também do gênero em questão neste estudo:

Com tal temperamento e tais qualidades de inteligência estava indicado a Otaviano um gênero em que certamente haveria de distinguir-se: o da crônica, ou melhor do seu precursor, que foi o folhetim. A imprensa brasileira não era mais a mofina distribuidora de notícias e descomposturas. Já não estávamos na situação lamentada por Maria Graham no primeiro reinado, quando os bons leitores dificilmente poderiam encontrar nas escassas folhas pasto para a fome intensa de literatura. (COUTINHO, 1971, pp. 77-78).

Colaborando no Jornal do Comércio de 1852 a 1854, conforme indica Coutinho (1971), Otaviano dá início, com a seção $A$ Semana, à divulgação do folhetim que, mais tarde, seria adotado por Machado de Assis e José de Alencar, que, posteriormente, se tornariam cronistas - entre muitos outros escritores consagrados. Foi, portanto, importante figura não somente nas questões relativas à movimentação jornalística e política, mas, sobretudo, literária.

Alceu Amoroso Lima (1960 apud COUTINHO, 1971, p. 78-79) afirma ter sido pelas influências de Otaviano que José de Alencar tornou-se o precursor do gênero cronístico. Para ele, a crônica "participa, ao mesmo tempo, de duas tendências muito comuns em nosso temperamento nacional - o espírito lírico e o espírito crítico”3 ${ }^{\text {. }}$

Outro nome importante no tocante à divulgação da literatura é José Ferreira de Souza Araújo (1846-1900). Ferreira Araújo é citado por Coutinho (1971, p. 85) como 
aquele que "soube fazer do seu jornal um grande órgão de interesse literário". O jornal é citado por Coutinho é a Gazeta de Notícias.

No período republicano a expansão dos jornais continuou a ocorrer, apesar de repressões do Governo Provisório. Mas, nesse momento, os jornais já deixaram de ser suporte para o percurso dos políticos e passou a ser um veículo de disseminação e comunicação feito pelos intelectuais. Coutinho (1971) vincula este novo papel do jornal como veículo das produções literárias ao grau de cultura e estabilidade política da região.

Trata-se, portanto, de um patamar alcançado extremamente distante daquele brevemente relatado aqui que contemplava o início do século.

A imprensa brasileira adquiria um caráter burguês, deixando de lado suas características artesanais (SODRÉ, 1999, p. 261). Isso quer dizer que a imprensa tornou-se uma indústria e que trabalhava para tal.

Segundo Sodré (1999, p. 276), há um aspecto contraditório entre as relações de poder e o desenvolvimento da imprensa nesse período. Existia uma forte instabilidade política no país com a sucessão dos chefes de Estado, gerando intrigas e conflitos entre a burguesia em ascensão e o latifundiário, por tanto tempo dominante. Dessa forma, a imprensa, que já possui uma face capitalista e burguesa, precisava se adequar a um governo que ainda não se adaptara ao capitalismo, pois ainda tinha fortes raízes no passado colonial e feudal. Conseqüentemente, surgem jornais que atacam outros jornais que viviam à sombra do governo.

$\mathrm{Na}$ transição do século XIX para o XX, o Brasil era um país que ainda se mantinha pelo capital comercial, além de pelas áreas agrícola e pecuária. Numa esfera já superada pelos países desenvolvidos do período, a imprensa brasileira capitalista estava sob o poder de um Estado pré-capitalista e à base desse capital comercial, 
como afirma Sodré (1999, p. 278). Essa característica do Brasil estagnou o desenvolvimento da imprensa brasileira.

Tal estagnação trouxe uma fase de empobrecimento dos jornais e da literatura. Segundo Sodré (1999, p. 289), não há registros de grandes figuras literárias de transição entre os séculos, nesse período, apenas raros casos como Euclides da Cunha, que estreou no início do século.

Era por meio dos jornais que os escritores ganhavam dinheiro, assim como notoriedade. Sodré (1999, p. 292-293) mostra que os jornais que davam destaque à literatura eram Diário Mercantil, O País, Novidades, Correio do Povo, A Notícia e A Imprensa. Também no novo século figuravam o Jornal do Comércio, A Gazeta de Notícias e o Correio da Manhã, entre outros. E ainda complementa:

A verdade é que, a despeito de tudo, escreveu-se bastante durante os cinqüenta anos que aqui se examinam. Entre romancistas, contistas e dramaturgos, foram, para este ensaio, levantadas, nas histórias literárias, dicionários biobibliográficos e catálogos de livrarias, mas de duzentos nomes. Destes, a maioria está hoje completamente esquecida, sendo que, de vários outros, só mesmo os nomes e os títulos das obras puderam ser encontrados, visto como nem a Biblioteca Nacional nem nos livreiros antiquários existem os seus livros; [...]. (SODRÉ, 1999, P. 289).

A afirmação acima mostra como são urgentes as pesquisas em busca da produção literária do final do século XIX e meados do XX.

A estrutura das páginas dos jornais ia mudando gradativamente. O folhetim foi sendo substituído pelo colunismo; o artigo político pela entrevista; com destaque para os temas policiais e esportivos; como afirma Sodré (1999, p. 296). Nota-se que, aos 
poucos, a imprensa adotou a forma capitalista, com o objetivo de atingir o máximo de leitores possíveis, caindo a característica de veículo divulgador apenas de fatos sobre e para o poder do Estado, como acontecia no século anterior. Tratava-se de um novo perfil, com mais diversidade.

Sodré (1999) afirma que duas figuras dominaram a imprensa no início do século XX: Alcindo Guanabara e Paulo Barreto, ambos jornalistas, mas cada um com suas peculiaridades. Alcindo era "muito mais jornalista", caracteristicamente político, do movimento abolicionista do século anterior ao início do século XX, atacava o governo e defendia suas idéias. Paulo Barreto era muito mais escritor do que jornalista, participou da transição da folha tipicamente literária para a política, foi inovador na utilização de novas técnicas como a reportagem e a entrevista e representava com mais assiduidade a rotina do Rio de Janeiro.

Era no jornal que os profissionais da literatura iam buscar o que não entravam no livro: fama e dinheiro. Segundo Sodré (1999), Olavo Bilac e Medeiros e Albuquerque tinham salários mensais pelas crônicas que publicavam na Gazeta de Notícias e em O País. Assim como Alphonsus de Guimaraens para atuar como redator no jornal $A$ Gazeta. Portanto, os profissionais das letras atuavam em paralelo nos jornais, garantindo o que não conseguiam se só se dedicassem aos livros, principalmente neste momento em que os periódicos se abriram para a literatura, seja por meio de romances publicados em folhetins, crônicas, contos, ensaios ou poesias. 


\subsection{Folhetim: a origem da crônica}

A criação do Folhetim no século XIX teve como objetivo principal a comercialização dos jornais. Segundo o professor José Alcides Ribeiro (1996), a relação dos jornais com seu público-leitor já neste período era uma relação empresa versus consumidor, com a adoção de uma nova fórmula, o Folhetim, com o objetivo de aumentar as vendas.

Percebendo que havia um público carente no tocante às publicações das folhas, Émile de Girardin, padronizou a publicação da sessão Folhetim e criou uma rotina de publicações literárias e de interesses sociais.

As folhas brasileiras também adotaram o folhetim. Segundo a professora Marlyse Meyer (1996) os jornais brasileiros imitavam as publicações dos folhetins franceses, inclusive traduzindo suas crônicas, seus artigos, suas notícias. Foi neste espaço que a literatura nacional ganhou repercussão.

Coutinho (1971) afirma que o folhetim nasceu para dar liberdade aos autores, porém no pé da página dos jornais franceses, uma vez que não seriam aceitas nas principais colunas dos jornais.

No Brasil, o folhetim foi publicado inicialmente de forma anônima. Segundo Coutinho (1971), os primeiros folhetins assinados datam de 1846 a 1848 e foram de autoria de Luís Carlos Martins Pena, especialista em teatro e, por isso, os folhetins versavam sobre esse tema. Foi com Francisco de Otaviano que o folhetim ganhou sua característica de retratar o dia-a-dia.

Sintetizando o pensamento de Coutinho (1971, p. 92-93) sobre a importância do jornal em relação à literatura e seu caráter folhetinesco temos que "o jornal se 
apresenta veículo do pensamento político e social”; "(...) por meio dos folhetins e dos suplementos, o jornal faz o papel de verdadeira revista literária, difundindo peças de literatura pura" e "proporciona aos homens de letras uma atividade lucrativa que mais facilita a produção literária".

Um dos importantes gêneros que também se fixou e que ganhou popularidade graças à sua veiculação na seção Folhetim foi o romance-folhetim. Esse novo gênero garantiu a entrada de novos autores no mundo literário. Tratava-se de um espaço mais barato do que a publicação de um livro.

Após um período de sucesso do romance-folhetim na França, o golpe de Estado de 1851, dado por Luís Napoleão Bonaparte, trouxe repressão à Paris e foi determinada uma alta taxa para a publicação do gênero nos jornais. Assim, ocorreu uma pausa nas publicações, encerrando o primeiro período do romance-folhetim.

Depois que Napoleão Bonaparte assumiu o reinado como Napoleão III, é importante destacarmos a Paris que prevalecera. Estava consolidada a Paris industrial, tanto no segmento siderúrgico como nos segmentos têxteis e químicos. Há o "desenvolvimento da fotografia" e o "culto da máquina". Tratava-se de uma nova fase na sociedade parisiense, que, portanto, refletia na formação do público-leitor de jornais e também na configuração do próprio periódico.

Esse período foi caracterizado pelas censuras, prisões, punições e multas. E, justamente por isso, também foi um rico período para o jornalismo. Primeiro porque toda essa repressão aguçou os ânimos da imprensa, dos jornalistas, dos literatos para se manifestarem contra o Império. Segundo, porque essa imprensa "com voz ativa" incentivou o surgimento de outro tipo de imprensa, a popular, que começou a representar mais de perto a classe popular. Além da repressão do governo, a imprensa também sofreu as influências do processo industrial, permitindo o aumento das 
tiragens e atingindo um público cada vez maior, como aqueles que vieram do campo para a cidade.

Neste contexto de transformações na sociedade e na imprensa, é claro que o romance-folhetim, sucesso dos jornais há pouco tempo, voltaria - apesar de sofrer certa censura devido à repressão do governo.

Um novo público surgiu com o advento da Terceira República, em substituição ao Segundo Império. Era um público formado por operários das fábricas, sobreviventes aos massacres à tentativa de sua emancipação.

Michel Gillet ${ }^{4}$ completa:

O folhetim funciona como um objeto de aculturação parisiense. O que ele comenta, o que ele interpreta, o que ele afabula são outras mímicas, outros ruídos, outras cenas: a felicidade de ser moderno numa Paris haussmaniana [...]. Ele privilegia o papel de legitimação da capital como o espaço das intrigas e dos poderes. (GILLET, s.d., p. 18 apud MEYER, 1996, p. 227).

Quando os jornais brasileiros percebem o sucesso do gênero na França, passam a investir vorazmente em suas traduções. As traduções de romances-folhetins de autores não tão famosos como Eugène Sue eram publicadas no Jornal do Comércio desde 1839 no Brasil. Em 1843 o Jornal do Comércio procurou a obra Les Mystères de Paris, de Eugène Sue, e iniciou sua publicação diária em 1844. Em seguida, foi anunciada a venda do romance em livro.

Nesse ritmo frenético, muitas vezes os jornais não davam conta de receber os originais e traduzi-los em tempo para que saíssem sem interrupções. Neste caso os 
jornais recorriam a desculpas ao leitor e inseriam no lugar algum outro romance que estivesse engavetado.

Assim como em Paris, os jornais brasileiros descobriram no romance-folhetim um recurso ao sucesso das vendas.

Dependendo do sucesso do romance-folhetim ocorria uma nova publicação em momentos diferentes, em jornais diferentes e traduzidos por profissionais diferentes. Tudo com o intuito de cativar o leitor.

Em geral, a grande maioria dos jornais foi contaminada pela novidade francesa. Os editores adaptavam suas folhas conforme as exigências desse gênero. Mudavam os formatos, a diagramação, a veiculação das matérias. Faziam o que fosse necessário para não perderem de vista essa "mina de ouro".

Uma informação interessante é que os jornais chegavam a ter muito mais leitores ocasionais do que propriamente compradores ou assinantes. Isso ocorria porque nesse período as pessoas tinham por hábito emprestar os jornais aos vizinhos, aos parentes, aos amigos, talvez por falta de dinheiro para a aquisição diária da folha. Dessa forma, os jornais não eram vistos como "descartáveis" como hoje.

Essa avalanche de traduções de romances-folhetins também incentivara a criação de autores nacionais. Tentando seguir as regras básicas do gênero, que são o suspense, o corte ao final de cada dia e o melodrama, muitos autores se aventuraram nessa empreitada. No entanto, a maioria ainda não estava acostumada ao ritmo frenético dessa publicação e não acertavam o ponto dos romances. Segundo Marlyse (1996), um dos mais eficientes escritores do período e que se destacaram no gênero foi Raul Pompéia. Além do romance-folhetim, ele também se destacou nas crônicas. Marlyse também cita José de Alencar, com a publicação de O Guarani. 


\subsection{A crônica}

Nota-se que a democracia desse espaço denominado Folhetim era grande. Quase tudo que se destacava como bem cultural era destinado a essa seção. No Folhetim "se contam piadas, se fala de crimes e monstros, se propõem charadas, se oferecem receitas de cozinha ou beleza", completa a professora Marlyse Meyer (1992). Segundo o professor José Alcides Ribeiro esta seção

[...] agregava também uma série de artigos sobre o teatro, as artes plásticas, a literatura nacional e estrangeira, as revistas estrangeiras, a indústria, as viagens, os pequenos eventos sociais e as reuniões artísticas, literárias e mundanas.

[...] tudo o que haverá de constituir a matéria e o modo da crônica à brasileira já é, desde a origem, a vocação primeira desse espaço geográfico do jornal, deliberadamente frívolo, oferecido como chamariz aos leitores afugentados pela modorra cinza a que obrigava a forte censura napoleônica. (RIBEIRO, 1996, p. 25).

O professor Wellington Pereira (2004) reforça a característica híbrida da seção folhetinesca:

[...] qualquer manifestação lingüística que não se inscrevesse dentro das normas do jornalismo praticado no século XIX, geralmente doutrinário, recebia a denominação de folhetim. Daí entendemos que o conto, o romance, a novela e a crônica eram denominados folhetins a partir do espaço que ocupavam nos jornais. (PEREIRA, 2004, p. 40). 
Dessa forma, a crônica era inicialmente, assim como o romance, os contos e outros gêneros, publicada nessa seção Folhetim com o objetivo de entretenimento.

O termo crônica, etimologicamente, vem do grego Cronikós, relativo a tempo. No entanto, ao longo dos séculos, seu significado foi se modificando de acordo com a evolução da sociedade.

Segundo Wellington Pereira (2004, p. 16) "em sua estruturação, o mais importante era a organização cronológica dos fatos". Não havia, como diz o professor, uma intenção de enunciar os fatos, mas sim de anunciar por meio de uma ordem cronológica dos fatos.

A partir do século XII, na França, na Inglaterra e na Espanha, a crônica começa a adquirir, além de sua especificidade cronológica, características de relato histórico e ficção literária, segundo Wellington Pereira (2004, p. 17).

Até o período Renascentista, século XVI, a crônica seguia com as características citadas. No entanto, agora ela começaria a ser confundida com outro gênero: o ensaio. Este, segundo Wellington Pereira (2004), caracterizado por interpretar os eventos e suas funções sociais.

Considerar a crônica como um modo de representação e expressão do ensaio é desconhecer a pluralidade de seus significados, porque o texto do cronista não é apenas a tentativa ou a possibilidade de ensaiar uma conceituação para alguns fatos de uma sociedade com tempos históricos determinados. (PEREIRA, 2004, p. 21).

O ensaio foi um gênero textual muito utilizado pelos ingleses nessa época. Segundo Coutinho (1971, p. 106), modernamente, acredita-se que seu início tenha ocorrido com Montaigne em 1596. No entanto, muito antes de Montaigne outros 
ilustres já haviam passado pelo gênero, como Platão, Sócrates, Teofrasto, Cícero, Sêneca entre outros.

A base da composição do ensaio é focada na oralidade. Coutinho (1971, p. 106) afirma que o ensaio "é muito próximo da maneira oral ou do pensamento que é captado no próprio ato e momento de pensar".

Sua composição é, portanto, a simplicidade e sua brevidade. Normalmente recorre à narração, descrição ou argumentação, no entanto, sem se prender a uma forma pré-determinada.

Em relação ao seu tema, o ensaio percorre os temas mais diversos. Pode ir do familiar ao informal, passando por paisagens, recordações de fatos ou interpretações da vida. Coutinho (1971) afirma que atualmente o ensaio também adquiriu o caráter de julgamento e que, portanto, pode avaliar, discutir e concluir sobre um determinado tema.

Essa falta de identidade da crônica como gênero foi amenizada a partir do século XIX, após longo período de equívocos sobre sua teorização, dificultando sua exploração como gênero.

No século XIX, segundo o professor Wellington Pereira (2004, p. 23) “o cronista não se limita a reproduzir as regras da retórica nem sobrepõe o estilo à clareza do enunciado". Isso quer dizer que as revoluções industriais e, conseqüentemente, as evoluções na comunicação em geral desse século, influenciam a produção de crônicas.

O cronista do século XIX reavaliava sua produção de textos e incorporava os pensamentos e as necessidades do novo período em suas crônicas. O novo cronista buscava expressar: 
[...] novas formas de expressão para obter unidade estética no exercício da crônica, avançando diante da concepção histórica e da necessidade de revelar fatos. [...] passa a enfocar as relações fragmentadas do mundo moderno, cujo modo de compreensão não tem como instrumento apenas o código literário. O cronista procura entender a nova ordem de enunciação imposta pela sociedade industrializada. (PEREIRA, 2004, p. 23).

Fica claro que a nova ordem econômica e social predominante na Europa influenciava os escritores em geral. O cronista não poderia deixar de sofrer fortemente essa influência porque, justamente nesse momento, seu maior canal de veiculação era o jornal e, por isso, ele tinha necessidade de acompanhar o rápido desenvolvimento desse veículo de comunicação. Além disso, essa mudança no conceito da crônica refletia também o novo perfil de leitor desse século.

Muitos críticos de literatura dizem que a crônica é caracteristicamente brasileira, devido ao seu estilo despojado. No entanto, a crônica, tecnicamente, ganhou força nos folhetins franceses ao lado de pequenos contos, ensaios e poemas em prosa, textos voltados ao entretenimento, no início do século XIX, quando os jornais passaram a ser diários.

Desde então a crônica não tem recebido a merecida importância. Considerada, por alguns, como um gênero menor, a crônica jornalística ganhou espaço na mídia diária - o jornal - e mais tarde alcançou os livros com um enfoque diferente, uma tendência da literatura contemporânea.

Com seu espaço garantido no jornal, a crônica assumiu também as características desse veículo. É um gênero que tende a sobreviver apenas às mesmas 24 horas do jornal, seu tempo de produção e espaço são limitados, limitando assim a 
criação do cronista. Sua estreita relação com a literatura é uma característica que entusiasma muitos estudiosos.

A crônica possui um estilo próprio como gênero literário que nasceu nos jornais, onde tudo é efêmero. Segundo Antonio Candido (1992), a diferença básica entre a crônica e os outros gêneros literários é sua capacidade de pegar o miúdo e mostrar nele uma grandeza, uma beleza ou uma singularidade insuspeitadas.

No Brasil, do século XIX, eram os homens das letras que trabalhavam na imprensa. Esta é a característica de um período em que os jornais brasileiros eram formados basicamente por pessoas das letras, ou seja, da literatura. Mais que isso, quem fazia jornal, fazia teatro, música, fotografia, política entre outras. Era um período em que todas essas artes não possuíam especializações, portanto, muitos se aventuravam em diversas vertentes.

Essas particularidades, provavelmente, enriqueceram as produções literárias, em especial a crônica, mas obrigavam o cronista a ter um ritmo ágil para acompanhar os episódios de referência, assim como as notícias jornalísticas. No entanto, permitia que seu autor desenvolvesse o lirismo reflexivo da literatura, aproximando a crônica da ficção literária.

Da mesma forma, como nos lembram Chalhoub et. al. (2005):

[...] muitos romances e contos escritos na segunda metade do século XIX foram publicados originalmente nos jornais, muitas vezes com uma pressão de prazos idêntica àquela que inibiria a qualidade das crônicas. (CHALHOUB et al., 2005, p. 10).

Portanto, outros gêneros sofriam da mesma pressão de escrita para os jornais. No entanto, a crônica, por tratar de assuntos pontuais, possuía a característica de se 
perder no tempo e não receber a atenção merecida como importante gênero jornalístico e literário.

Chalhoub et al. (2005) explicam que o cronista precisava buscar os fatos importantes ocorridos para que conseguisse manter um diálogo com o seu públicoleitor. Justamente uma das mais importantes características da crônica: sua capacidade de dialogar com o leitor, seja por meio do discurso direto seja assunto tratado.

Outras formas de identificação com seu público-leitor eram feitas por meio dos títulos e dos pseudônimos, muito utilizados no século XIX. Por isso, Chalhoub et al. afirmam que

A leitura das crônicas demanda, portanto, a seus intérpretes que aliem a atenção às redes de interlocução a partir das quais elas são escritas com o esforço cuidadoso para decifrar o processo de sua elaboração narrativa. (CHALHOUB et al, 2005, p. 14).

Afinal, a crônica é um gênero literário ou jornalístico? Várias vezes essa pergunta foi feita e continua sendo discutida no âmbito dos estudos de literatura e comunicação.

Há estudiosos que acreditam ser a crônica um gênero jornalístico porque foi com espaço garantido nesse veículo que alcançou reconhecimento. Outros defendem que a crônica seja um gênero que mescla gêneros da literatura com o gênero jornalístico.

O tempo tem provado que a crônica é um gênero que transita entre a literatura e o jornalismo, entre os livros e as folhas dos jornais, sem que para isso precise mudar sua estrutura de composição. 
É certo que foi por meio de sua veiculação nas folhas do século XIX e nas primeiras décadas do XX que ganhou notoriedade. No entanto, é preciso ressaltar que no século XIX a maneira mais "rápida" (entre aspas, porque se comparado com o século XXI, não era nada rápida a veiculação dos jornais desse período) e eficiente de chegar ao público era por meio dos jornais. Se a confecção de um jornal, nesse período, era muito cara, fazendo que poucos tenham sobrevivido, ou mesmo sobrevivido por pouco tempo, a confecção de livros era quase inviável.

$\mathrm{Na}$ verdade, até hoje, século XXI, nota-se a disparidade entre o custo de produção de um jornal e de um livro. São vários os fatores que os distanciam no tocante ao preço final para o leitor, como, por exemplo, matéria-prima, canais de distribuição, ausência de política governamental que incentive a distribuição do livro, entre outros fatores.

Dessa forma, é claro que a crônica desenvolveu-se de acordo com o veículo em que esteve inserida durante a maior parte de sua existência. No entanto, acredita-se ser equivocado restringi-la a esse ou aquele gênero. Dizer que há necessidade de transferi-la para o livro com o intuito de sobressair-se às matérias de jornais, como foi descrito por Jorge de Sá (2001), é reduzi-la a um texto que apenas consegue atingir o leitor fora do eixo onde, justamente, se desenvolveu. O que, provavelmente, é um equívoco.

O professor Wellington Pereira (2004) contribui efetivamente com seus estudos sobre a crônica para ajudar a entender como ela consegue ser tão híbrida a ponto de conseguir se adaptar aos suportes de comunicação sem prejuízo à sua concepção. Ele menciona a nova concepção de crônica, adotada após o período do Romantismo:

O cronista estabelece novos processos de enunciação, ultrapassa os limites impostos pela conotação, procurando transformar o exercício da crônica num espaço textual que absorve, criticamente, várias 
linguagens. Neste sentido, a crônica não se define apenas a partir do grau de literariedade nem do referencial jornalístico: torna-se a possibilidade de leitura dos níveis lingüísticos passíveis de uma reconstrução no interior do jornal. Para renovar a estrutura dos enunciados jornalísticos ou literários, o cronista constrói seu texto além das exigências denotativas ou conotativas que as conceituações emprestam à crônica no espaço jornalístico. (PEREIRA, 2004, p. 31).

Dessa forma, observamos que a crônica absorveu as características lingüísticas do jornal e da literatura, e se desenvolveu, principalmente, depois do século XIX, como um gênero à parte desses dois. Um gênero que não se limita mais às concepções do veículo em que está inserido:

A crônica cria um novo tempo narrativo no interior dos jornais, acrescenta relações semânticas que enriquecem a linguagem referencial do jornalismo informativo. Portanto, classificar a crônica como gênero jornalístico ou literário é negar a independência estética da crônica em relação às unidades narrativas do texto jornalístico. (PEREIRA, 2006, p. 141).

O professor Luiz Roncari ${ }^{5}$ também contribui com esse pensamento, conforme citação de Wellington Pereira (2004):

[...] a crônica usa e abusa da variedade dos pequenos gêneros, dos simples aos mais complexos, na sua composição: diálogo do cotidiano, retratos, tipos, cenas cômicas e dramáticas, versos, sonetos, relatos, narrativas, casos, comentários, contos, confissões, descrições líricas, 
sátiras, paródias etc. não temos ainda um estudo sobre a infinidade de gêneros não-literários (erroneamente procura-se na crônica os gêneros tipicamente literários, esquecendo-se que ela mesma não chegou a se cristalizar num, mantendo-se na fronteira, como um canal de comunicação ou zona de contato entre as esferas da alta baixa cultura) que absorve na sua constituição. (RONCARI, 1985, p. 14 apud PEREIRA, 2004, p. 141).

Para Antonio Candido (1992), do século XIX para cá, a crônica foi deixando a intenção de informar e tornou-se, cada vez mais, gênero de diversão. Sua linguagem ficou mais descompromissada, emprestando muito da poesia. Acredita-se que, justamente, por adquirir essa capacidade de divertir e de deixar o caráter informativo para outros gêneros, a crônica tem-se destacado no ambiente do jornal, agregando emoção a este veículo.

O gênero cronístico tem se fortalecido ao longo da história e também tem destacado vários escritores brasileiros. Diversos escritores partiram deste gênero para se sobressaírem em outros, como é o caso de Olavo Bilac. Outros escritores tiveram destaque em todos os gêneros nos quais se atreveram, como Machado de Assis. E tem-se, ainda, aqueles que se tornaram efetivamente cronistas, ultrapassando a barreira do espaço e do tempo, como Rubem Braga.

Candido (1992) acredita que a crônica consolidou-se no Brasil da década de 1930, como um gênero cultivado por um grande número de jornalistas e escritores. Essa teoria de Candido, provavelmente, tenha referência ao período político pelo qual passava a imprensa brasileira a partir dessa década. Até então, a imprensa vivia um período de estagnação devido ao sistema oligárquico que ainda, de certa forma, vigorava no poder estatal. Portanto, a partir do momento em que a imprensa começou 
a se manifestar como empresa capitalista e cresceu como tal, o jornal passou a ser também um espaço de participação dos importantes escritores que se destacavam ao mesmo tempo em outros gêneros literários.

Outra característica do gênero cronístico é sua tendência à historicidade. Para Margarida de Souza Neves (1992, p. 76), a crônica pode ser tratada como documento. A professora afirma que "de uma forma muito particular as crônicas recolocam a seus leitores a relação entre ficção e História".

Tratam-se, portanto, de documentos, no sentido de trazer ao leitor fatos e acontecimentos do período em que foram escritos e de também levar o leitor até esses momentos. "Documentos, porque monumentos de um tempo social", completa a professora (NEVES, 1992, p. 76). Destaca-se aí o caráter da crônica transpor os limites temporal e espacial, permitindo o resgate da memória e da história coletiva do período. Para a professora Margarida (1992, p. 82), “A crônica é sempre de alguma maneira o tempo feito texto, sempre e de formas diversas, uma escrita do tempo. Não fosse senão por essa razão, já seria justo que delas se ocupassem os historiadores".

Portanto, o aspecto documental da crônica atrai não só estudiosos da área das letras, mas também historiadores que estão em busca de mais que um resgate histórico, desejam "visualizar" o que se passou no período em que a crônica foi escrita.

Sobre a crônica, Afrânio Coutinho (1971, p. 93) afirma: "O próprio noticiarismo, por sua vez, em mãos de literatos, sem ter a estética como objetivo principal, ganha um tom harmônico que se avizinha, muitas vezes, da crônica".

Segundo Coutinho (1971), a crônica teve o seu primeiro significado direcionado ao caráter histórico. Foi nesse sentido que ela se desenvolveu em diversos idiomas, como o francês, o italiano e o inglês durante alguns séculos, como as crônicas que 
contribuíram para os relatos históricos desde o século XIII, mencionadas Coutinho (1971).

No entanto, foi no século XIX, que a crônica figurou como um gênero. Coutinho (1971, p. 109) afirma que "o uso da palavra para indicar relato e comentário dos fatos em pequena seção de jornais acabou por estender-se por definição da própria seção e do tipo de literatura que nela se produzia".

A crônica passou a ser considerada um gênero cujos temas poderiam ser os mais variados. Daí o seu foco principal não ser o tema, podendo percorrer do noticioso ao familiar, do cultural ao vulgar, mas, sim, o seu estilo leve e despretensioso que atinge os mais diversos leitores.

Sobre a relação do gênero cronístico com o folhetim, Coutinho (1982, p. 109) cita Machado de Assis, um dos mais hábeis cronistas. Machado já elucidava as características do cronista e do gênero mesmo ainda sendo relacionado ao folhetim em sua crônica publicada em 30 de outubro de 1859:

[...] o folhetim nasceu do jornal, o folhetinista por conseqüência do jornalista. Esta última afinidade é que desenha as saliências fisionômicas na moderna criação.

O folhetinista é a fusão admirável do útil e do fútil, o parto curioso e singular do sério, consociado com o frívolo. Estes dois elementos, arredados como pólos, heterogêneos como água e fogo, casam-se perfeitamente na organização do novo animal.

$[\ldots]$

O folhetinista, na sociedade, ocupa o lugar do colibri na esfera vegetal; solta, esvoaça, brinca, tremula, paira e espaneja-se sobre todos os caules suculentos, sobre todas as seivas vigorosas. Todo o mundo the 
pertence; até mesmo a política. ${ }^{6}$ (ASSIS, 1947 apud COUTINHO, 1982, p. 109).

Segundo Coutinho (1971) a crônica ganhou credibilidade nos jornais brasileiros quando a imprensa obteve características de grande empresa. Dessa forma, os novos atrativos que passaram a fazer parte dos jornais, como as ilustrações, os clichês fotográficos, a nova formatação dos cadernos com o aumento do número de páginas, estão diretamente relacionados a um jornal diferenciado e à propagação do gênero cronístico como recurso também de entretenimento.

Além disso, havia uma relação entre os cronistas e os romancistas, pois normalmente eram os mesmos que escreviam os dois gêneros. Coutinho (1971) afirma que os cronistas foram os primeiros romancistas e que romances surgiram primeiro na crônica e, posteriormente, se tornaram romance. É o caso de Memórias de um sargento de milícias, de Manuel Antônio de Almeida. Daí já se percebe facilmente o hibridismo do gênero cronístico, que segundo Coutinho (1971), foi também resultado da presença de vários gêneros na seção Folhetim do jornal, uma vez que folhetim era tudo que poderia ser publicado nesta seção.

Segundo os estudos de Coutinho (1982), o primeiro cronista brasileiro foi Francisco Otaviano de Almeida Rosa (1825-1889) que publicou em folhetim no Jornal do Comércio, do Rio de Janeiro, em 2 de dezembro de 1852. Porém, Coutinho (1982) também menciona o estudo do professor da Universidade de Brasília, Alamir Aquino Correia, que acredita ter sido a crônica inaugurada no Brasil por outros escritores como Josino Nascimento Silva (1811-1886), tendo-as publicado no jornal O Cronista entre 1837 e 1839; Padre Miguel do Sacramento Lopes Gama (1791-1851), que atuou 
em O Constitucional, de 1829 a 1831, e em O Carapuceiro de 1832 a 1847; e Luís Carlos Martins Pena (1815-1848), que atuou em alguns jornais do período.

Nessa época, meados do século XIX, a crônica alcançou a grande categoria intelectual por meio de José de Alencar. Substituindo Francisco Otaviano, teve suas crônicas publicadas no Jornal do Comércio, dividindo a seção com Manuel Antônio de Almeida. Coutinho (1971) cita que o título da seção era "Páginas Menores" e que, possivelmente, esse nome fora dado à seção para justificar a publicação de um gênero que era tido como menor em relação aos outros, e que, provavelmente, não suportaria o tempo.

Segundo Coutinho (1971), as crônicas de José de Alencar eram recheadas de fantasias, mas também refletiam o inconformismo em relação à sociedade e à política. O título de sua seção de crônicas era "Ao correr da pena". Machado de Assis deixou uma grande quantidade de crônicas foram publicadas em O Espelho, Diário do Rio de Janeiro, o Futuro, A Semana Ilustrada, Ilustração Brasileira, O Cruzeiro e Gazeta de Notícias.

Aproximadamente no período de Alencar e Machado, outros escritores se enveredaram pela crônica, como Joaquim Manuel de Macedo, Quintino Bocaúva, França Júnior, Artur Azevedo, Medeiros e Albuquerque, Aluízio Azevedo, João do Rio (Paulo Barreto) e Raul Pompéia. Esse último, que possui em O Ateneu o seu reconhecimento como escritor, publicou, segundo Coutinho (1982), seu romance fragmentado em capítulos na Gazeta de Notícias, com o nome de "Crônica de saudades".

A atuação de João do Rio como cronista também foi muito importante, pois segundo Coutinho (1982), ele inaugurou "a crônica social moderna". Com o objetivo de fazer da crônica um gênero dominante no período, final do século XIX e início do 
século XX, João do Rio se empenhava em "adaptar a sua percepção ao ritmo do progresso, de que o cinema e o automóvel eram duas ousadas expressões" (COUTINHO, 1982, p. 116).

[...] suas crônicas, quaisquer que sejam os artifícios e futilarias, além de conciliar esplendidamente o jornalismo e a literatura, adaptaram-se com extraordinária maleabilidade ao ritmo acelerado da vida contemporânea. Isso importava uma revolução, mas não obstante, em outros domínios, o gênero continuou a ser explorado pela maneira habitual ainda por longo tempo. (COUTINHO, 1982, p. 116).

O gênero cronístico desenvolveu-se nesse viés de uma sociedade que clamava urgentemente pela manifestação literária e que encontrou neste gênero uma oportunidade de expressão.

\subsection{0 gênero memorialístico}

Pela exposição referente ao gênero cronístico no item anterior constata-se ser um gênero que tende a trafegar por outros gêneros. Do conto à poesia, passando pelas memórias, o hibridismo da crônica a torna um gênero distinto de outros que se compõem uniformemente, sem a intervenção de outros.

Por ter aspectos temporais como uma de suas principais técnicas de composição, naturalmente a crônica tem o caráter memorialista em sua formação. A memória é um artifício que faz parte de suas bases de composição. 
Há, portanto, a necessidade de se fazer um breve levantamento sobre as características do memorialismo com o intuito de compô-lo no universo das crônicas, cujas características já foram apontadas anteriormente.

Nota-se o crescimento contínuo do cultivo do gênero de memórias. Escritores conceituados em outros gêneros renderam-se às memórias, como foi o caso de Oswald de Andrade. Por vezes, parece ser uma necessidade individual dos autores relatar e compartilhar suas experiências, elevando-as a um determinado patamar literário e acessível a todos os leitores.

Fávero (1999, p. 24) aponta a literatura de memória como uma "produção variada, desnivelada, com propósitos ora voltados para o dado essencialmente histórico, ora almejando atingir planos mais elevados da elaboração artística".

Segundo Afonso Henrique Fávero (1999, p. 9), a presença do gênero memorialístico na literatura do Brasil remonta ao final do século XIX, consolidando-se nas primeiras duas décadas do século $X X$ com os movimentos de vanguarda $e$ também com "uma literatura mais consolidada". Antes disso, do século XVIII a meados do século XIX, os gêneros poesia, prosa, ficção e teatro não possuíam referências aos textos de memórias. Fávero (1999) afirma que foi a partir da década de 1930 que a literatura possuía mais publicações de obras memorialísticas.

Sodré$^{7}$ aponta o período de nascimento da literatura de memórias na segunda metade do século XIX:

[...] na maior parte livros de assentos, simples registros de fatos ligados diretamente a quem escreve, que o impressionam e exigem a escrita, e a correspondência começa a ter função um pouco além do seu caráter utilitário e imediato. É raro, entretanto, no início da

7. SODRÉ, Nelson Werneck. O que se deve ler para conhecer o Brasil. 5. ed. Rio de Janeiro: Civilização Brasileira, 1976, p. 345. 
segunda metade do século, a consagração do livro para memórias, assentos ou correspondências. [...]. (SODRÉ, 1976 apud FÁVERO, 1999, p. 27-28).

Fávero (1999, p. 30) cita a obra Como e Por que sou Romancista de José de Alencar como um marco inicial de literatura de memória, publicado em 1893.

Antonio Candido (apud FÁVERO, 1999, p. 51) acredita que o memorialismo brasileiro ganhou força com a publicação de Memórias, Sinceras e Medíocres de Humberto de Campos em 1933.

Um traço recorrente à literatura de memória é sua tendência de não ser finalizada por seu autor, já que, muitas vezes, ele morre antes de seu término. Fávero (1999, p. 32) afirma que isso ocorreu com vários escritores, como Pedro Nava, Graciliano Ramos, Érico Veríssimo, Oswald de Andrade, Brito Broca, entre muitos outros.

A questão sobre o verossímil presente no memorialismo e, por vezes, documental em relação ao que está sendo exposto vem sendo debatida e questionada por críticos literários. Trata-se da evolução do pensamento sobre um gênero cujas características se norteavam nesse aspecto, e que agora, outros pontos são tomados como referências.

Northrop Frye, importante crítico literário, expõe sobre a questão da autobiografia e o verossímil, em sua obra Anatomia da crítica:

A autobiografia é outra forma que se mescla com o romance por uma série de gradações insensíveis. A maior parte das autobiografias é inspirada por um impulso criador, e portanto ficcional, a selecionar apenas aqueles acontecimentos e experiências da vida do escritor que 
vão construir uma forma integrada. (FRYE, 1973 apud FÁVERO, 1999, p. 18).

Portanto, há aqui uma questão importante sobre o gênero memorialístico. Tratase de não se vincular a ele a característica de verossimilhança, não a tomando como um dos principais fatores de sua composição.

É importante mencionar que não houve qualquer intenção de analisar a verossimilhança nesta pesquisa quando se detectou que a obra de Helena Silveira é composta, em sua maioria, por memórias.

Joaquim Alves de Aguiar contribui sobre a questão da verossimilhança no gênero memorialístico da produção de Pedro Nava:

Certamente, tanto os manuais de história quanto os de literatura não costumam dar destaque aos memorialistas. Num campo e noutro, talvez o gênero seja considerado menor, um subgênero, pelo subjetivismo das impressões, prejudicial à objetividade que se espera do historiador; pela adesão ao retrato, que pode empobrecer o texto ficcional. No campo da crítica literária, o maior problema foi sempre medir os graus de verdade e verossimilhança no discurso memorialístico. Em princípio, mais próximas do verídico que os demais gêneros, com muito de testemunho e de confissão, as memórias acabaram sendo catalogadas numa espécie de gênero próprio, menor entre os maiores, o "memorialismo", através do qual vêm logrando o reconhecimento do seu estatuto literário. (AGUIAR, 1998 apud COHEN, 2005, p. 15).

Na citação de Aguiar, nota-se que o gênero memorialístico tem ganho espaço para além de ser simplesmente uma documentação histórica. Além disso, Aguiar cita 
ser o gênero memorialístico, menor que outros, mesma enfermidade de que sofre o gênero cronístico.

Uma interessante menção de Luiz Roncari aponta o caráter híbrido da crônica que muito se aproxima do gênero memorialístico:

Constituindo-se em gênero heterogêneo e flexível, ao contrário dos gêneros jornalísticos, que se afirmam sempre por uma identidade bem definida (editorial, reportagem, artigo de fundo etc), a crônica usa e abusa da variedade dos pequenos gêneros, dos mais simples aos mais complexos, na sua composição: diálogos do cotidiano, retratos, tipos, cenas cômicas e dramáticas, versos, sonetos, relatos, narrativas, casos, comentários, contos, confissões, descrições líricas, sátiras, paródias etc. (RONCARI, 1990 apud COHEN, 2005, p. 28).

O gênero memorialístico apresenta, segundo Fávero (1999), o caráter de refletir a situação em que se encontra a "realidade brasileira", pois "refletiam o meio que se situava o autor". Isso significa que a análise da obra memorialística pode conter importantes traços da sociedade brasileira do período.

Fávero (1999) ainda compara os textos de memórias aos romances no tocante à sua contribuição literária:

[...] os textos de memórias acabam por desempenhar papel análogo ao do romance, com a diferença de que aqueles não necessitam, em princípio, apresentar a fatura estética própria deste último. Ocorre, entretanto, que muitas vezes apresentam. Ganham vulto artístico, ombreiam-se com os melhores romances, utilizam-se de suas técnicas, chegam a confundir-se com eles. (FÁVERO, 1999, p. 29). 
Assim como a crônica, o gênero memorialístico também se aproxima da ficção. É claro que a produção das memórias, seja em romance, contos ou crônicas, podem recorrer à imaginação para compor a narrativa de um determinado fato. Por não possuir como caráter essencial em sua concepção a verossimilhança, a narrativa memorialística tende a se utilizar das técnicas de composição das narrativas ficcionais para enaltecer sua composição artística.

William Spengemann ${ }^{8}$ expõe a relação de memória e da invenção:

Para recapturar no presente os sentimentos que permearam 0 passado, portanto, o narrador deve reviver a vida do protagonista em vez de simplesmente refletir sobre ela do seu ponto de vista no presente. Apesar da reflexão ser um instrumento apropriado e necessário de autoconhecimento, auto-realização requer expressão espontânea - não reflexão mnemônica, mas ação imaginativa. (SPENGEMANN 1980 apud COHEN, 2005, p. 14). 


\section{FUNDAMENTAÇÃO TEÓRICA}

\subsection{Foco narrativo ou ponto de vista}

O foco narrativo ou ponto de vista será abordado neste capítulo como o principal aspecto da análise literária. Serão abordados seus principais tópicos e aplicados posteriormente no capítulo "Crônicas de memória: visões sobre a morte" na análise das crônicas de Helena Silveira.

Em relação ao foco narrativo numa narrativa havia e, ainda há, um malentendido no tocante à presença do "autor" como narrador. Por diversas vezes, tem-se que a voz e, conseqüentente, o ponto de vista daquele que detém a narração é do autor, aquele cuja presença física se faz na concepção da obra. Com base nesse equívoco tinha-se que uma narrativa em terceira ou em primeira pessoa era condição determinante para se caracterizar o narrador e, fatalmente, o autor.

No entanto, segundo Dal Farra (1978), esta concepção caiu graças aos estudos de Booth e Kayser, que determinaram a inviabilidade da "categoria de pessoa" para um estudo retórico ficcional. Ambos concordaram que um romance ou uma narrativa em primeira ou em terceira pessoa possuem como característica comum a presença de um "narrador como máscara do autor". Isso significa que uma narrativa que contiver um narrador em primeira ou em terceira pessoa não refletirá mais nem menos a presença do autor. Sempre haverá a predominância de um narrador que disfarçará as intenções do autor. Este, por sua vez, se fará explícito raramente, pois o narrador funcionará como intermediário de suas vontades. 
O reconhecimento desse narrador, ainda que superficial, se faz por meio de minuciosas análises dos aspectos temporais e espaciais, da seleção de signos, da constância de pontuações e das tipologias literárias. É necessário, então, que uma série de detalhes sejam considerados no tocante à análise do foco narrativo, tem-se que ampliar a visão para além desse aspecto. É exatamente o que se propõe fazer neste estudo por meio de análise do foco narrativo, da temporalidade e das tipologias jornalísticas e cronísticas.

Considerando os estudos de Genette, o narrador é chamado de narrador onisciente. Trata-se de um narrador que determina o direcionamento da linha a ser seguida ao longo da narrativa. O narrador onisciente se faz existente graças à sua capacidade de manipular os personagens, o tempo e o espaço da narrativa. É por meio dele que o foco narrativo é determinado.

Todorov (1970) expõe um ponto fundamental para a compreensão dessa questão do narrador. Ele afirma que, quando o narrador da enunciação se inclui também no enunciado, seu papel dentro da narrativa muda:

O personagem-narrador não é, pois, uma personagem como as outras; não se assemelha tampouco ao narrador de fora [...]. Isso seria confundir o 'eu' com o verdadeiro sujeito da enunciação, que conta o livro. No momento em que o sujeito da enunciação se torna sujeito do enunciado, não é mais o mesmo sujeito que enuncia. Falar de si próprio significa não ser mais "si próprio". O narrador é 'inominável': se quisermos dar-lhe um nome, ele nos permite o nome, mas não se encontra por detrás dele: refugia-se eternamente no anonimato. (TODOROV, 1970, p. 47). 
De acordo com Dal Farra (1978), a questão do foco narrativo está, freqüentemente, muito restrita à visão apenas do narrador. Esquece-se que por trás desse narrador há o narrador onisciente, aquele que faz uso do narrador para se manifestar. É possível, portanto, ainda segundo Dal Farra (1978) que

[...] o ângulo de visão conferido ao narrador seja um dos possíveis ângulos formadores da ótica do 'autor-implícito' ou do 'criador mítico do universo' ou do 'narrador onisciente' ou de qualquer que seja o nome que se dê a esta mente detentora dos poderes romanescos. (DAL FARRA, 1978, p. 23).

Vê-se na definição de Dal Farra que o narrador onisciente pode ser determinado por várias nomenclaturas. Neste estudo, priorizou-se o termo narrador onisciente por ser esta a nomenclatura mais utilizada pelos teóricos aqui considerados, como Genette e Todorov.

Da mesma forma que por meio da análise do foco narrativo é possível reconhecer parte do perfil do narrador onisciente, é também possível que haja uma exposição enganosa contida nesse narrador com o objetivo de se criar uma ilusão em relação à sua intenção. É necessário atentar-se para aquilo que vê e expõe o narrador e aquilo que ele não vê, conforme aponta Dal Farra:

Assim, quando se considera o ponto de vista do narrador, deve-se levar sempre em conta, ao mesmo tempo, o que ele vê e o que ele não vê: o que ele foi levado a "não enxergar" para que o autor-implícito pudesse disso tirar proveito. (DAL FARRA, 1978, p. 25).

A definição de Littré sobre foco narrativo é uma das principais que melhor define a sua função dentro do discurso: 
Nome dado às diferentes formas do verbo empregadas para afirmar mais ou menos a coisa de que se trata, e para exprimir [...] os diferentes pontos de vista dos quais se considera a existência ou a ação. (LITTRÉ apud GENETTE, 1995, p. 160).

Com base em Littré, Genette (1995) expõe que o foco narrativo está estreitamente interligado ao modo narrativo. A narrativa pode expor ao leitor os fatos de maneiras diferentes, segundo o foco narrativo adotado, o que fará toda a diferença, pois o leitor terá acesso a fatos diversos, de acordo com o determinado foco narrativo. Mesmo narrativas distintas escritas por um mesmo autor podem apresentar diferentes focos narrativos, o que pode acontecer também dentro de uma mesma narrativa. Ou seja, o ponto de vista pode mudar ao longo da narrativa; ele não é uma estrutura fixa que permanece inerte do início ao final da narrativa. $E$ isso também não acontece somente numa narrativa considerada de caráter extenso, como o romance. O conto e a crônica são dois gêneros que exploram esse recurso do foco narrativo alternado.

O foco narrativo, portanto, é o recurso responsável pelos graus de informação e pelos detalhes que o discurso proporcionará ao leitor.

Segundo Genette (1995), o foco narrativo é caracterizado principalmente por duas categorias: a distância e a perspectiva. A distância consiste nos graus em que a informação narrativa é transmitida, pois ela pode ocorrer em graus diversos. A narrativa pode fornecer informações incompletas ao leitor, de forma que ela mantenha distância daquilo que está narrando. Já a perspectiva refere-se ao "ponto de vista", ou seja, a narrativa fornece informações ao leitor segundo um determinado ponto de vista em relação à história.

Sobre o modo narrativo, Genette (1995, p.166) propõe: "pode-se contar mais ou menos aquilo que se conta, e contá-lo segundo um ou outro ponto de vista". Ele ainda 
cita uma referência de Mendilow ${ }^{9}$ ao romance no que diz respeito às narrativas em primeira pessoa e em terceira pessoa, que se julga, nesse momento, fundamental reproduzir devido à seleção de crônicas presentes neste estudo:

Contrariamente ao que se poderia esperar, o romance na primeira pessoa raramente consegue dar a impressão da presença e da imediatidade. Longe de facilitar a identificação do leitor com o herói, tende a parecer afastado no tempo. A essência de tal romance é a de ser retrospectivo, estabelecer uma distância temporal reconhecida entre o tempo da história (o dos acontecimentos que se deram) e o tempo real do narrador, o momento em que conta esses acontecimentos. Existe uma diferença capital entre uma narrativa virada para a frente a partir do passado, como romance em terceira pessoa, e uma narrativa virada para trás a partir do presente, como romance em primeira pessoa. No primeiro tem-se a ilusão de que a ação está em vias de se dar; no segundo, a ação é apercebida como já se tendo dado. (MENDILOW apud GENETTE, 1995, p. 166).

A obra de Todorov (1970) é uma referência para a construção do pensamento estruturalista e, portanto, julga-se extremamente pertinente a sua referência neste capítulo no tocante ao foco narrativo.

Todorov (1970) na mesma linha de pensamento de Genette (1995), expõe que [...] o termo visão ou ponto de vista (...) se refere à maneira por que os acontecimentos narrados são percebidos pelo narrador e, conseqüentemente, pelo leitor virtual. As visões estão ligadas muito de perto aos registros da fala. (TODOROV, 1970, p. 40).

9. MENDILOW, A. A. Time and the novel. Londres: Editora, 1952, p. 106-107. 
Os conceitos de Todorov e de Genette se complementam: para Genette contar não é mais que o modo pelo qual o enunciador se mostra em seu discurso e configura o conteúdo que será disposto; e, para Todorov, o ponto de vista é a maneira pela qual o narrador vê e expõe a narrativa. Os dois conceitos expostos configuram a importância que há no modo pelo qual a narrativa é contada pelo narrador, considerando o ponto de vista adotado. Dessa forma, o que importa aqui é o processo de enunciação da narrativa e não o enunciado em si, como propõe Todorov (1970).

Em literatura, jamais temos de haver-nos com acontecimentos ou fatos brutos, e sim com acontecimentos apresentados de determinada maneira. Duas visões diferentes do mesmo fato fazem destes dois fatos distintos. Todos os aspectos de um objeto se determinam pela visão que dele nos é oferecida. (TODOROV, 1970, p. 41).

A citação de Todorov (1970) mostra a importância que existe na consideração do ponto de vista no que se refere aos estudos da narrativa. Segundo ele, os fatos podem ser entendidos de modos totalmente diferentes apenas considerando o foco narrativo, que significa que uma mesma narrativa pode ser exposta de diversas maneiras de acordo com o foco narrativo adotado.

De acordo com Henry James (apud DAL FARRA, 1978, p. 28), "há cerca de cinco de milhões de formas diferentes de se contar uma história". Nota-se, portanto, que o foco narrativo é determinante para a constituição da narrativa. É um aspecto que, ao ser ignorado, resulta em uma análise pouco criteriosa. 


\subsubsection{Perspectiva}

A perspectiva trata da escolha ou não de um determinado foco narrativo. Segundo Genette (1995), é comum que se confunda, de acordo com a perspectiva, o modo e a voz da narrativa representados, respectivamente, pelas perguntas: "Qual é a personagem cujo ponto de vista orienta a perspectiva narrativa?" e "Quem é o narrador?". Aqui, Genette (1995) deixa clara a diferença entre ambos os aspectos: no modo está contida a orientação que leva ao ponto de vista; já a voz se refere à voz narrativa, à identidade do narrador.

Genette (1995) cita Todorov (1970), o qual resume a questão da perspectiva e desfaz a possível confusão entre modo e voz. As fórmulas de Todorov (1970) são:

- "Narrador $>$ personagem $\rightarrow$ narrador sabe mais que a personagem ou, mais precisamente, diz mais do que aquilo que qualquer personagem sabe;

- Narrador $=$ personagem $\rightarrow$ o narrador apenas diz aquilo que certa personagem sabe;

- Narrador < personagem $\rightarrow$ o narrador diz menos do que sabe a personagem";

Tomando como referência as fórmulas de Todorov, Genette explica o foco narrativo, respectivamente, como:

- Focalização zero - é o caso do narrador onisciente, que sabe mais que a personagem (narrador > personagem).

- Focalização interna - neste caso, o narrador se manifesta por meio da personagem, dizendo apenas aquilo que a personagem permite; o narrador 
adota o ponto de vista da personagem, portanto o narrador é igual à personagem (narrador $=$ personagem).

- Focalização externa - o narrador ocupa uma posição externa na narrativa e, portanto, sabe menos que a personagem (narrador < personagem).

Pela exposição anterior, nota-se que o conceito de focalização está intimamente ligado à situação do narrador no processo discursivo.

Genette (1995, p. 189) complementa: "a fórmula de focalização nem sempre se aplica ao conjunto de uma obra, portanto, mas antes a um segmento narrativo determinado, que pode ser muitíssimo breve". Isso significa que a focalização sofrerá variações ao longo do discurso e, portanto, o ponto de vista também será abalado por essas variações.

Para Todorov (1970), a questão da focalização também está relacionada à situação do narrador no discurso:

Há um limite infranqueável entre a narrativa onde o narrador vê tudo quanto vê seu personagem, mas não aparece em cena, e a narrativa em que o personagem-narrador diz 'eu'. Confundi-los seria reduzir a linguagem a zero. (TODOROV, 1970, P. 42).

Todorov (1970) explicita que a posição do narrador pode ser muito diversa dentro de uma narrativa. A relação do narrador com a narrativa determinará o foco narrativo adotado.

A organização do texto para a definição do foco narrativo é definida pela perspectiva. Duas importantes definições de perspectivas podem ser citadas. A primeira, de Genette (1995, p. 183): “(...) segundo modo de regulação da informação, 
que procede da escolha (ou não) de um 'ponto de vista' restritivo [...]". E a segunda definição de perspectiva, de Denis Bertrand (2003):

À diferença do ponto de vista, que implica um observador, a perspectivização é da alçada da textualização. Ela consiste na escolha que o enunciador faz, levando em conta as coerções da linearidade, ao selecionar o percurso narrativo deste ou daquele ator em detrimento de tal ou tal outro, igualmente presente na cena narrativa. Assim, no romance policial, a escolha consistirá em colocar o leitor na perspectiva do investigador, do criminoso ou da vítima [...]. (BERTRAND, 2003, P. 427).

Percebe-se, até aqui, que a focalização e a perspectiva caminham juntas, pois ambas, ao fazerem uma seleção de foco ou de perspectiva a partir do processo discursivo, descartam outras possibilidades. Assim, sempre hão de descartar alguma parcela de um discurso em prol de outro.

Segundo Todorov (1970), aparentemente simples, a narrativa contém um narrador-personagem é a mais complexa no tocante à análise. Há maior complexidade em uma narrativa dessa categoria, em que existe um narrador-personagem, do que na narrativa em que o narrador não entra em cena.

A narrativa que contempla um narrador-personagem também provoca um distanciamento entre o tempo da história e o tempo real. Trata-se de uma narrativa voltada para o passado, conforme Mendilow ${ }^{10}$ (1952 apud GENETTE, 1995, p. 166).

Acredita-se ser típico de um narrador-personagem usufruir de metáforas para compor o arsenal de influências sobre a compreensão do leitor virtual.

10. Idem, ibidem, p. xx. 
O conceito de leitor virtual foi destacado por Todorov e representa um leitor que está inserido na obra, que nada tem a ver com o leitor real. É, portanto, uma das visões literárias da obra e não a visão do leitor real:

É importante notar que as visões literárias não concernem à percepção real do leitor, que permanece sempre variável e depende de fatores externos à obra, mas à uma percepção inerente à obra, atribuída a um destinatário virtual, apresentada no interior dessa obra, se bem que de uma maneira diferente de seus outros elementos. (TODOROV, 1970, p. 41).

Sob a ótica de um narrador-personagem, tem-se na crônica uma narrativa de acontecimentos, pois se trata de uma mera imitação de mimese - longe de ser a mimese definida anteriormente por Platão -, com focalização interna. Ou seja, o foco dessa narrativa é direcionado unicamente para aquilo que o narrador e a personagem, que são os mesmos, permitem que seja dito conforme o seu próprio ponto de vista. Segundo Genette (1995), tem-se, neste caso, uma focalização interna, que significa que o narrador e a personagem são iguais e que, portanto, um e outro adotam o mesmo ponto de vista.

A questão da focalização é um aspecto que determina o ponto de vista adotado na narrativa. Investigar a focalização e, portanto, o ponto de vista na narrativa permite a observação das estruturas literárias mais essenciais, o que não acontece ao se renegar a sua existência.

Da mesma forma, como afirma Genette (1995), a mudança de focalização ao longo do discurso remete a outro ponto de vista, o que pode acontecer com certa freqüência. No entanto, pode ocorrer, também, uma alteração muito pontual no ponto de vista, que não seja necessariamente relevante no contexto do discurso. 
Algumas dessas alterações podem ser denominadas paralipses, uma omissão parcial de fatos no discurso. Outras alterações do ponto de vista são as paralepses, que, ao contrário, tratam-se da presença de informação desnecessária. Segundo Genette (1995), essa segunda alteração - a paralepse - pode ocorrer por meio da "incursão na consciência da personagem", provocando assim quantidade excessiva de informação.

Outra questão importante citada por Genette (1995) é a distinção que se deve fazer entre "a informação dada por uma narrativa focalizada e a interpretação que o leitor é convocado a dar-lhe". Isso significa que, dentro de uma narrativa, os fatos podem não ser vistos claramente pelos personagens, mas que, para o leitor, eles podem estar muito claros.

A polimodalidade ocorre quando numa narrativa se utiliza dos três tipos de focalização: interna, externa e a não-focalização.

Um recurso utilizado para que não haja alteração da focalização interna é o uso de locuções como talvez, sem dúvida, como se, parecer, aparecer como, que permitem ao narrador destacar assuntos que, caso os dissesse sem esse recurso, teria que mudar a focalização. Essas locuções podem também ser, ao contrário, “indicadores de focalização”, como afirma Genette (1995, p. 201).

\subsection{Tempo de narração}

Segundo Genette (1995), é possível relatar uma história sem situá-la no espaço em que ocorre, porém é impossível não localizá-la no tempo - presente, passado ou 
futuro. Assim, "as determinações temporais da instância narrativa são manifestamente mais importantes que as suas manifestações espaciais" (GENETTE, 1995, p. 215). Essa determinação temporal é caracterizada de acordo com a história em que está inserida. É a inter-relação estabelecida entre a temporalidade e a história que determinam o tipo da narração.

Buscar a caracterização do ritmo da narrativa é fundamental para o reconhecimento da sua diversidade temporal e para a compreensão de que o tempo da narrativa é muito diferente do tempo da diegese (história).

O ritmo de uma narrativa não é definido segundo a sua apresentação - como por meio da divisão de capítulos -, mas sim por meio de recursos gramaticais que permitem a descontinuidade da narrativa. Esses recursos são percebidos no nível macroscópico, e são compostos por recursos gramaticais reconhecidos como anisocronias.

\subsubsection{Anacronias}

Chama-se anacronia àquilo que está em desacordo com a sua época. Segundo Genette (1995),

Estudar a ordem temporal de uma narrativa é confrontar a ordem de disposição dos acontecimentos ou segmentos temporais no discurso narrativo com a ordem de sucessão desses mesmos acontecimentos ou segmentos temporais na história, na medida em que é indicada explicitamente pela própria narrativa ou pode ser inferida deste ou aquele indício indireto. (GENETTE, 1995, p. 33). 
Genette (1995) exemplifica a presença da referência temporal de forma direta ou explícita nas narrativas clássicas: "três meses antes etc". Trata-se de uma oscilação indicada pela temporalidade. Para o entendimento da narrativa é preciso que se considere aquilo que virá depois dessa cena na narrativa e daquilo que se acredita ter vindo antes na diegese.

Esse é justamente o jogo das anacronias. É um contraste entre a ordem dos fatos na narrativa e na história. Trata-se de um recurso, segundo Genette (1995), muito antigo na história da literatura ocidental.

As anacronias narrativas são recursos presentes nas narrativas pelos quais é possível haver uma transição entre o tempo da história principal e o tempo anterior a ela. São consideradas anacronias as analepses e as prolepses, detalhadas a seguir:

- Analepses

Abaixo serão citados os tipos de analepses segundo os conceitos de Genette (1995, pp. 47-49), porém esse nível de detalhamento não será utilizado na análise por se julgar aqui dispensável devido ao objetivo do estudo. Os tipos de analepses são:

a) Analepses mistas: alcançam o ponto anterior ao da primeira narrativa e, depois, terminam num ponto posterior ao começo da narrativa primeira;

b) Analepses externas ou heterodiegéticas: por serem externas, não interferem na narrativa primeira. São apenas complementos à narrativa primeira; 
c) Analepses internas, homodiegéticas ou repetitivas: seu campo de atuação está estritamente ligado ao da narrativa primeira e, portanto, pode interferir na narrativa.

d) Analepses parciais: são analepses que não terminam na narrativa principal, mas sim numa elipse, ou seja, num salto à frente.

e) Analepses completas: são aquelas que se religas à primeira narrativa, sem solução de continuidade entre os dois segmentos da história.

Genette (1995, p. 52) explica que as analepses não se referem apenas a uma "fração do tempo passado"; elas podem remeter a várias frações. Isso explica por que com o gancho de uma determinada narrativa principal podem ocorrer regressos a várias situações que a complementam ou não.

- Prolepses

Segundo Genette (1995, p. 72), a prolepse tem menos ocorrência do que a analepse pela própria tradição da narrativa ocidental. Antecipar os fatos tende a não manter o mistério, elemento típico dos romances. "São alusões antecipadas a um acontecimento que será a seu tempo contado de uma ponta a outra."

Abaixo serão citados, como foi feito com as analepses, os tipos de prolepses segundo os conceitos de Genette (1995, pp. 47-49), porém esse nível de detalhamento não será utilizado na análise por se julgar aqui dispensável devido ao objetivo do estudo. Os tipos de prolepses são: 
a) Prolepses internas - também geram interferência à narrativa;

b) Prolepses completivas - têm o objetivo de completar com uma informação a situação do presente;

c) Prolepses generalizantes - trazem uma perspectiva sobre uma série ulterior;

d) Prolepses repetitivas - Trata-se de anúncios, assim como as analepses repetitivas tratam de retorno. São introduzidas com expressões como "Veremos" ou "Como havemos de ver" etc. Esses anúncios têm a função de criar "expectativa no leitor";

e) Anúncio versus esboço - O esboço é um elemento imperceptível que, somente ao longo da narrativa, ganhará sua função. Já o anúncio contribui de alguma maneira com a situação do presente, porém será relatado posteriormente;

f) Marcas de prolepses - "Para antecipar", "desde"; "antecipo" etc;

\subsubsection{Tipologia da dimensão noticiosa das crônicas: tipologia da linguagem jornalística e cronística}

De acordo com Van Dick (1990), somente a partir da década de 1960, o estilo passou a ser relacionado ao contexto social em que estava inserido, graças à sociolingüística. Essa ciência passou a considerar a idade do indivíduo, seu status e sua classe social como fatores de motivação para as variações da linguagem. 
Tradicionalmente, o estilo e a estilística estavam associados à unidade pessoal e à estética da linguagem. Portanto, supunha-se que a composição do estilo fosse neutra, sem variedades, e que as variações encontradas no discurso eram não mais desvios dentro do estilo pré-determinado.

Para Van Dick (1990), a comparação é a base da existência e do questionamento do estilo. Portanto, quando se fala em estilo, entende-se que há alguma variante em qualquer um dos fatores que o compõem. Da mesma forma, é necessário que haja algo que não participe dessa variação para que, efetivamente, ocorra a comparação entre os estilos.

Os fatores aos quais Van Dick (1990) se refere são um conjunto de detalhes que compõem as estruturas do discurso, desde variantes do contexto social ao qual pertence o indivíduo responsável pela notícia até as suas características como indivíduo.

Em geral, Van Dick (1990) tem como foco as possibilidades dos diversos grupos sociais quando da composição do discurso. O autor frisa que as variações estilísticas são sinais de determinados grupos sociais e de sua cultura. Isso significa que pessoas de diferentes grupos sociais podem dizer a mesma coisa de modos diferentes sobre um mesmo assunto. Portanto, a alteração não será semântica, mas sim estilística.

O estilo de um indivíduo sofrerá influência de acordo com o grupo social ao qual pertence e também de acordo com a situação daquele discurso, o meio em que esse discurso está inserido etc.

Por exemplo, o contexto textual é o conjunto de características associado a um contexto social particular. O contexto dos medias está ligado aos meios de comunicação, entre outros. 
No caso da crônica, tem-se um discurso que mescla as características noticiosas, por ser um discurso veiculado nos periódicos, com outros diversos aspectos literários. Como citado anteriormente, a crônica é um gênero que transita entre os periódicos e a literatura, e que, às vezes, pode causar estranhamento devido ao seu hibridismo.

Neste estudo, pode-se destacar alguns aspectos noticiosos presentes nas crônicas de Helena Silveira, mas que não representam sua totalidade. Em geral, Helena retrata em suas crônicas situações de sua própria experiência de vida.

Van Dick (1990) afirma que um texto de periódico pode possuir menções a aspectos históricos denominados por ele como antecedentes. Tal fator se refere a acontecimentos informativos que podem ter ocorrido há anos e que promovem a compreensão do discurso. Trata-se de uma das características do discurso noticioso. 


\section{CRÔNICAS DE MEMÓRIA: VISÕES SOBRE A MORTE}

Inicialmente, este capítulo seria composto pela análise das crônicas de Helena Silveira - no tocante às temáticas, às tipologias e ao foco narrativo - , selecionadas a partir de uma leitura que as julgasse pertinentes a tais características. No entanto, após leitura minuciosa de suas crônicas, percebeu-se que a morte é a temática mais

recorrente ao longo da obra Sombra Azul e Carneiro Branco. Isso fez que a composição deste capítulo fosse repensada e redirecionada à análise das crônicas cuja tipologia temática fosse a morte. Independente das sessões às quais pertence, possuem singularidades, que serão tratadas em detalhes posteriormente.

\subsection{Especificações do corpus}

A obra Sombra Azul e Carneiro Branco de Helena Silveira, objeto de estudo desta dissertação, é dividida em quatro seções de acordo com os temas: gente, bichos e coisas, crônicas de Natal, paisagem e memória, nessa ordem. Segundo Helena Silveira, essa seleção foi feita com base em seu estado de espírito e não necessariamente de maneira cronológica.

As seções não possuem a mesma quantidade de crônicas. O livro possui 64 crônicas divididas da seguinte maneira: 10 crônicas na seção Gente; 12 crônicas na seção Bichos e coisas; três crônicas na seção Três crônicas de Natal; e 39 crônicas na seção Paisagem e memória. 
Trata-se de uma seleção de crônicas que, segundo Helena (1960), em seu prefácio, "representam 15 anos de trabalhos quase sempre diários". O livro foi publicado pela Editora Cultrix em 1960 e faz parte da Coleção Letras Brasileiras. Segundo os editores da obra, ela "tem por objetivo apresentar ao público ledor de nosso país, em volumes de boa apresentação gráfica, textos de autores nacionais que se recomendem pelo interesse e pelo mérito literário". ${ }^{11}$

Em seu prefácio, Helena Silveira (1960) demonstra o quanto estima o gênero crônica, diferenciando-se daqueles que o produziam como mera fonte de renda: "Meu hábitat válido é o dia-a-dia inconseqüente da crônica, este escrever sobre areias, esse fincar raízes no efêmero".

Helena informa ter catalogado as crônicas nessa edição de forma aleatória, sem qualquer pretensão de marcar o tempo, mas com o objetivo de retratar situações, pessoas, bichos e paisagens. E deixa claro que, no momento de sua transposição do jornal para o livro, respeitou a sua própria criação:

Do retalho do jornal para que se destina, a crônica não pode passar ao livro com modificações. [...] Crônicas são espécies de castelos de areia. Ao mudá-las para o livro, parece-nos singular pagar imposto pelo sonho... Entretanto, o que não se pode fazer é mudar a areia para o cimento armado. De nenhum modo... (SILVEIRA, 1960, p. 10).

Nesse breve comentário de Helena sobre o gênero, entende-se que a autora respeita as particularidades da crônica e valoriza a capacidade do gênero de migrar entre os meios de comunicação.

11. SILVEIRA, Helena. Sombra Azul e Carneiro Branco. São Paulo: Cultrix, 1960. Texto de orelha. 


\title{
4.2 Análise das crônicas
}

Afrânio Coutinho (1971) cita Helena Silveira entre uma das mais importantes colaboradoras para o desenvolvimento do gênero cronístico no século XX - mais uma justificativa para a relevância deste estudo.

\begin{abstract}
Embora seja temerário estabelecer-se um vínculo de geração ou escola, entre cronistas, não há dúvida de que foi a atmosfera de renovação pós-1930 que favoreceu o desenvolvimento desse gênero sob novos e múltiplos aspectos, com Ribeiro Couto [...], Cecília Meireles, Helena Silveira, Dinah Silveira de Queirós, Adelson Magalhães, Gustavo Corção. (COUTINHO, 1971, p. 119).
\end{abstract}

Cada uma das crônicas de memória de Helena Silveira na obra Sombra Azul e Carneiro Branco tem características muito próprias, e há singularidades que merecem ser destacadas com o objetivo de caracterizar e confrontar as suas técnicas de composição na categoria de crônicas memorialísticas.

Com o objetivo de se demonstrar uma análise minuciosa das crônicas memorialísticas serão estudadas detalhadamente 4 das 20 crônicas que têm a morte como temática. A seleção foi feita com base na diversidade estrutural das crônicas e na sua complexidade. A caracterização das crônicas tem como principal objetivo o reconhecimento de suas técnicas de composição, partindo da temática referente à morte. Pretende-se, ao final, demonstrar como é a relação da autora com a temática.

Ao final deste estudo, as 20 crônicas cuja temática está relacionada à morte serão incorporadas como anexo com o objetivo de contribuir com a consulta de suas crônicas. 
As crônicas de Helena Silveira publicadas em Sombra Azul e Carneiro Branco cuja seleção foi feita pela própria autora, são tipicamente formadas pelo memorialismo. No entanto, é preciso destacar que esse memorialismo não condiz, necessariamente, com o caráter de autobiografia cuja essência também é o memorialismo. As crônicas de Helena Silveira trazem memórias de infância, de família, de amigos e de fatos do dia-a-dia. Por esses temas, outros aspectos usualmente cronísticos são evidenciados na obra, como, por exemplo, o retrato de costumes da época, a ambientação social e política. Não se encontra aqui uma autobiografia convencional de Helena Silveira, mas memórias ambientadas em situações diversas sob a forma de crônicas.

Em relação às temáticas das crônicas de memória de Helena Silveira pode-se distinguir duas categorias nas quais elas se baseiam: crônicas de memória da infância e crônicas de memória adulta.

É importante lembrar que as crônicas selecionadas por Helena Silveira foram primeiramente publicadas no jornal Folha da Manhã na seção chamada "Paisagem e memória”. No período de sua publicação no jornal, já havia a preocupação de destacar que tais crônicas tratavam de suas memórias.

Vale comparar a obra Sombra Azul e Carneiro Branco a outra obra de Helena Silveira que leva o nome da seção de crônicas "Paisagem e memória", uma seleção de crônicas do período de 1940 a 1950, publicada em 1983, percebe-se que suas crônicas são, em sua maioria, centradas no caráter memorialístico. O gênero memorialístico é uma constante nas obras de Helena Silveira.

Helena relata histórias vividas por ela e reconstrói nas crônicas suas experiências de vida. Ela divide com o leitor suas experiências com os amigos, com os familiares e, principalmente, relata as perdas que a morte lhe causara. A seguir, iniciaremos a análise das crônicas. 


\subsubsection{Crônica: A viagem e o beijo}

\subsubsection{Temática}

Em "A viagem e o beijo" a temática principal é a morte. É relatada a morte de sua mãe. Uma rememoração do seu encontro com a mãe falecida.

Fui levantada por braços poderosos, meu rosto roçou o rosto da mulher agonizante, os soluços de todos os lados davam-me a idéia de uma extrema e inenarrável desgraça.

$[\ldots]$

Tinha um ano e meio quando beijei minha jovem mãe agonizante, e no fundo do coração era o medo e as trevas.

Nas crônicas memorialísticas de infância de Helena Silveira nota-se claramente o aspecto de ficção na narração dos fatos. Um exemplo pertinente é relato do conhecimento da criança, com um ano e meio de idade ao se deparar com o velório da mãe, em meio a muitas pessoas.

[...] Abriram-me uma porta, empurraram-me ao lado da irmã maior. Em torno, havia uma aura expectante de tragédia, e isso eu jamais esquecerei. Era como se me houvesse tornado numa periclitante ilhazinha, que o terrível mar ameaçasse de cobrir. A caminhada teria de ser até o fundo do quarto claro, com uma cama onde jazia uma jovem mulher [...]. Eu caminhava medrosa de nunca chegar. Era possível haver na terra tal distância? [...] 
As metáforas, evidentemente, completam as lembranças que, provavelmente, não eram muito claras para uma criança de um ano e meio. Elas recheiam a fantasia que o adulto criou sobre o acontecimento.

Após essa reflexão, percebe-se o quanto é possível haver de ficção ou de imaginação na composição de crônicas de memória que recordam fatos da infância. É evidente que, após longo período, a própria mente modifique as lembranças do cronista ou mesmo que, propositadamente, o cronista inclua a fantasia em suas memórias. Esse último aspecto pode ser totalmente pertinente, uma vez que a crônica de memória não exige fidelidade em seus relatos. O que é valorizado é sua capacidade de compor os fatos e as possíveis memórias.

Essa característica de preocupar-se com o detalhe ou com um fato simples do cotidiano, atraindo a atenção a ele, como Helena fez nesta crônica, é o que permite "superar os limites do cotidiano" (SOUSA, 2005). Sérgio (2005), afirma, ainda, que é por meio da linguagem que o cronista consegue ocupar um espaço diferenciado nas folhas dos jornais, exatamente o que aconteceu com Helena Silveira, que colaborou por mais de 40 anos nos periódicos, em especial no grupo Folha. Luiz Roncari (apud SOUSA, 2005, p. 155) afirma que o cronista "faz uso do 'eu', do gosto e dos caprichos pessoais" para obter esse resultado diferenciado.

As crônicas de memória de Helena Silveira são pautadas por acontecimentos do cotidiano, pela rememoração do miúdo, dos pequenos e até dos grandes acontecimentos de sua vida pessoal.

Em relação às técnicas de rememoração, em estudo sobre as memórias de Augusto Meyer, Fávero (1999) explicita ser impossível que haja reconstituição perfeita do que passou quando o adulto relata em suas memórias as experiências da infância. 
No caso de Augusto Meyer, Fávero (1999) expõe uma reflexão do próprio Meyer ${ }^{12}$ sobre essa questão, que, devido às várias referências de Helena Silveira às suas memórias de infância, julga-se muito pertinente a reprodução seguinte:

A reconstituição da infância, seja numa tentativa autobiográfica ou em qualquer forma de evocação literária, já se apresenta viciada na origem pela perspectiva de ilusão e mesmo de transfiguração em que se coloca o adulto, para poder descrevê-la; digo transfiguração num sentido geral e não somente a que retoca para melhor e ameniza as recordações, avivando as ensolaradas e omitindo as sombrias.

Existe uma transfiguração miúda e cotidiana das cousas, que mal percebemos, e acaba por tornar irreconhecíveis as palavras e gestos de há um mês, de há um ano - quanto mais todo esse mundo confuso e balbuciante, no começo da vida, separado de nós, homens feitos, pela poderosa máquina de amoldar, enformar e reprimir que é o determinismo social, batizado neste caso com o nome de educação. (MEYER apud FÁVERO, 1999, p. 64).

O narrador relata fatos acontecidos bem distantes da sua realidade atual. Percebe-se, nitidamente, uma grande distância entre os dois tempos.

Na crônica em estudo, o narrador-personagem usufrui desse recurso para expor ao leitor a cena narrada: "Em torno, havia uma aura expectante de tragédia, e isso eu jamais esquecerei. Era como se me houvesse tornado uma periclitante ilhazinha, que o terrível mar ameaçasse de cobrir". 


\subsubsection{Tipologia da linguagem jornalística e cronística}

O recurso que fundamenta a transição e a articulação entre os tempos da narrativa e da diegese é a anacronia. Trata-se de uma ferramenta que possibilita a transição entre a cena principal e o tempo anterior ou posterior a ela.

A crônica em questão é uma narrativa construída sobre a rememoração de fatos da infância que, ainda na vida adulta, influenciam o percurso do narrador.

Por meio de uma leitura apurada da crônica selecionada, foi considerada uma microanálise, com o objetivo de elucidar os recursos da anacronia narrativa.

Com a finalidade de facilitar a determinação das anacronias, é situado o período que pode ser considerado como a primeira narrativa temporal, segundo Genette (1995). Tal denominação significa que esse é o período que regerá a subordinação dos outros períodos. Trata-se, portanto, do período principal da narrativa: "Entretanto, lembro-me hoje de outra viagem, que me parece muito mais longa que todas essas, e num território grande e pleno de mistérios".

É a partir desse período que a narrativa tende a se "desenrolar". Após situar a primeira narrativa, destacam-se nessa crônica três posições temporais. Foram localizadas analepses internas, evocações de fatos anteriores que influenciam a narrativa. As analepses poderiam ser denominadas como externas e seriam evocações de fatos anteriores que não influenciariam o desenvolvimento da narrativa. A presença das analepses praticamente determina a narrativa, pois ela é quase toda uma rememoração de fatos da infância. 
Há algumas variações de prolepses, segundo Genette (1995). No entanto, aqui foram localizadas apenas as prolepses generalizantes, que trazem uma perspectiva sobre fatos posteriores.

Por meio das prolepses, o narrador faz no passado uma enunciação do que será sua vida após a morte de sua mãe. Há o julgamento de que toda a sua trajetória será influenciada por aquele momento.

Ao final da crônica há um grande período repleto de prolepses:

Depois, foi o retorno até a porta, o jardim, os dias, as flores, as mesas, as comidas, os brinquedos, as doçuras. Mas a caminhada na infância tão remota, para aquela despedida, estendeu-se-me vida afora. Foi a viagem mais longa. Ao voltar, seria um navio largando para sempre o porto.

Mas, mais do que anunciar um futuro no passado, as prolepses permitem que a narrativa cumpra seu papel de gênero cronístico no tocante à sua especificidade de poder dialogar com o seu leitor. Como é o caso do último período do último parágrafo: Terá consciência o navio-fantasma, que deixa assim uma angra, dos vendavais que o esperam e, sobretudo, da impossibilidade de jamais encontrar amarras que o segurem na bonança e na paz?

A primeira posição temporal é a primeira narrativa situada no presente. A segunda posição temporal consiste nas lembranças de momentos já na fase adulta, com o relato de viagens e a vivência em diferentes culturas, localizada no primeiro parágrafo da crônica: "Já caminhei algo pelo mundo. Já transpus espaços largos em navio e avião. Andei por 'Oropa, França e Bahia' e mergulhei [...] gutural”. 
A terceira posição temporal é a retrospecção que determina toda a narrativa. Esta última ocorrerá em vários momentos durante a narrativa. É iniciada ainda no meio do primeiro parágrafo: "Teria ano e meio, e uma visão de baixo para cima fazia que as pernas dos homens fossem altas como mastros, os trincos das portas inalcançáveis, os rostos perdidos em brumas de distâncias (...)".

Situar essas três posições temporais caracteriza claramente a presença das anacronias. Numa leitura linear, sem o desmembramento dos tempos é fácil que esse recurso passe despercebido.

Segundo Genette (1995, p. 38), as analepses são "toda a ulterior evocação de um acontecimento anterior ao ponto da história em que está" e as prolepses são "toda a manobra narrativa consistindo em contar ou evocar de antemão um acontecimento ulterior". Assim, podem ocorrer dois tempos dentro das anacronias.

No tocante às prolepses, Genette (1995) menciona que elas aparecem em menor número nas narrativas. Um dos motivos se dá porque elas tendem a contribuir para o desvendamento de mistérios.

A narrativa de mistérios, como nos romances, não é um recurso próprio da crônica. Portanto, aqui as prolepses se encontram em número considerável, porém, da mesma maneira como ocorre nos romances, ainda em menor ocorrência do que as analepses.

Retomando o conceito, explicitado por Genette (1995), as prolepses são antecipações de fatos, sejam eles do presente no passado, sejam eles do futuro no passado. Elas podem ocorrer com subordinação à narrativa principal ou até mesmo em subordinação às analepses. O primeiro caso ocorre em "(...) e isso eu jamais esquecerei. Era como se (...)". Trata-se de uma antecipação subordinada à narrativa principal. 


\section{- Anisocronias - efeitos de ritmo}

No caso da crônica "A viagem e o beijo", há a presença de algumas importantes anisocronias, que, apesar de uma crônica relativamente pequena, permite o desenvolvimento do seu ritmo.

As anisocronias fazem uso de vários recursos. Um deles é a elipse. Algumas serão destacadas na crônica em estudo.

O primeiro parágrafo da crônica "A viagem e o beijo" é repleto de uma das mais importantes formas que conferem movimento à narrativa. Trata-se da elipse hipotética. É um recurso que não nos permite desvendar em que tempo da diegese tais situações ocorreram.

O narrador lembra acontecimentos de sua vida, pessoas e lugares que conheceu, mas não determina em que momento tudo isso ocorreu e tampouco a ordem desses

fatos. É, portanto, uma elipse mais do que implícita, conforme pode ser visto a seguir: Já caminhei algo pelo mundo. Já transpus espaços largos em navio e avião. Andei por "Oropa, França e Bahia" e mergulhei até naquele Oriente Médio onde devem estar a lâmpada de Aladim e a cruz de Cristo. Foram incursões em territórios (...).

As elipses implícitas também estão presentes nessa crônica. No último parágrafo da narrativa, o narrador anuncia: "Depois, foi o retorno até a porta, o jardim, os dias, as flores, as mesas, as comidas, os brinquedos, as doçuras”. Há a indicação de que, após a criança ter enfrentado a morte de sua mãe, teria de enfrentar as outras coisas da vida. Da mesma maneira que a hipotética, não há definição clara do momento, mas é possível percebê-la pela sua própria disposição na narrativa e pelo recurso do 
advérbio "depois". Portanto, é uma elipse implícita apontando que o anunciado virá após os fatos ocorridos, no caso, após a morte da mãe.

Também podem ser ilustradas as elipses explícitas. Como a própria definição da elipse sugere, é explícita a sua presença por meio da indicação determinada "teria ano e meio". Esta é a mais simples de ser verificada: "Teria ano e meio e uma visão de baixo para cima fazia que as pernas dos homens fossem altas como mastros, os trincos das portas inalcançáveis, os rostos perdidos em brumas de distâncias (...)". (grifo nosso).

A presença das elipses na crônica providencia o ritmo da narrativa. Nos pontos em que elas ocorrem temos o registro de que o tempo da narrativa é nulo, mas o tempo da diegese pode ser infinito. Portanto, é possível, segundo Genette (1995), determinar esse movimento elíptico pela fórmula: $\mathrm{TN}=0$ e $\mathrm{TH}=n$; logo $\mathrm{TN}<\infty \mathrm{TH}$, em que $\mathrm{TN}$ é o tempo da narrativa e TH é o tempo da história ou da diegese.

\subsubsection{Foco narrativo}

A crônica "A viagem e o beijo" é composta por um narrador-personagem, segundo as definições de Todorov (1970). Como já exposto, toda narrativa que possui um narrador-personagem tende a ser mais complexa porque, aparentemente, direciona o leitor a um ponto de vista unilateral.

No caso desta crônica, além de um narrador-personagem, há também um narrador adulto que rememora uma longínqua infância. Este é um aspecto que tem de ser considerado porque um narrador-personagem já apresenta um exclusivo ponto de 
vista. Porém, quando se trata de um adulto narrando um determinado fato de sua infância, passa a existir a questão da imaginação muito forte nesta narrativa de memória.

Conforme Spengemann (1980 apud COHEN, 2005, p. 14), citado na fundamentação teórica, é necessário que o narrador reviva aquela vida que o protagonista da narrativa quer expor; não basta o narrador relatar segundo o seu ponto de vista. E para isso é preciso que ele faça uso da "ação imaginativa".

Fávero (1999) ainda complementa:

Sendo naturalmente obras voltadas para a vida que ficou para trás, uma primeira visão que delas podemos obter seria quanto à postura de seus narradores diante desse passado. Não será difícil observar as variações de perspectiva em torno desse aspecto. (FÁVERO, 1999, p. 13).

Em uma narrativa de memórias como essa, o ponto de vista torna-se permeado pela atitude imaginativa, pois não há como se validar as memórias de adulto em relação aos seus dois anos de idade. Além desse aspecto, está embutida nessas memórias toda uma experiência de vida que e entrelaça à imaginação para compor a narrativa.

Recorrendo-se diretamente à crônica, recuperam-se essas observações. Logo no primeiro parágrafo o narrador diz: "E não acredito que jamais viaje tanto em profundidade, extensão e tempo, mesmo que atravesse todos os meridianos e siga a rosa-dos-ventos de todas as estradas do mundo".

Neste trecho já se nota o caráter de avaliação do adulto em relação ao fato da infância. Esse vai-e-vem entre os dois mundos - o da infância e o do adulto - ocorrerá diversas vezes. Essa mescla entre esses dois mundos é o que melhor caracteriza o 
ponto de vista nesta crônica. Isso porque, por mais que o narrador relate as memórias sob o ponto de vista daquela criança de dois anos, inevitavelmente é um adulto que o está fazendo e sua vivência e avaliação dos fatos tornam-se inevitáveis.

Cita-se outro exemplo que confirma essa avaliação:

Teria ano e meio, e uma visão de baixo para cima fazia que as pernas dos homens fossem altas como mastros, os trincos das portas inalcançáveis, os rostos perdidos, em brumas de distâncias.

$[\ldots]$

Fui levantada por braços poderosos, meu rosto roçou o rosto da mulher agonizante, os soluços de todos os lados davam-me a idéia de uma extrema e inenarrável desgraça. Depois foi o retorno até a porta, o jardim, os dias, as flores, as mesas, as comidas, os brinquedos, as doçuras. Mas a caminha na infância tão remota, para aquela despedida, estendeu-se-me vida afora. (grifo nosso).

O trecho grifado reflete bem a questão do ponto de vista de ser elaborado por um narrador-personagem adulto, que levou para a sua rememoração toda uma vida que se desenvolveu após o fato da morte de sua mãe ter ocorrido. Trata-se de uma visão diferenciada do narrador-personagem sobre o passado.

Outro recurso que nesta crônica representa a questão do ponto de vista é a exploração da metáfora. Por meio dela, o narrador expõe, diversas vezes, a sua opinião sobre a situação daquela criança que está vendo a mãe falecida.

A caminhada teria de ser até o fundo do quarto claro, com uma cama onde jazia uma jovem mulher de cabelos desfeitos nas alvuras dos travesseiros, e ela própria toda desfeita, como uma pobre rosa por demais desabrochada, no momento exato em que vai deixar cair todas as suas pétalas. (grifo nosso). 


\section{$[\ldots]$}

Mandavam-me caminhar, e eu caminhava fora e dentro de mim mesma. Caminhei um século, um continente, um mundo. A figura ao fundo do quarto era um altar em que se processava uma liturgia que se tornou depois em minha religião. (grifo nosso).

Os dois trechos grifados representam observações de um narrador-personagem adulto que reflete a respeito do momento de encontro com a mãe morta. O primeiro é uma metáfora a respeito sobre a aparência da mãe, que, com certeza, não tinha sido observado por aquela criança com menos de dois anos. Neste trecho o narrador mistura partes de sua memória com uma imagem formada sobre o momento; ele, portanto, faz uso da imaginação para narrar aquela situação. O segundo grifo traz um narrador que expõe as conseqüências daquele momento em sua vida. Trata-se de uma oscilação temporal entre aquela infância e o que o narrador-personagem se tornara. 


\subsubsection{Crônica: Encontro com meu pai}

\subsubsection{Temática}

Nesta crônica o tema principal é a morte do pai. Por meio de uma fantasiosa descrição, O narrador relata um encontro imaginário com seu pai, já morto, e retoma sutilmente lembranças da personalidade do pai. A crônica é construída com base na imaginação e na memória de narrador-personagem.

Logo no segundo parágrafo da crônica já é possível perceber que Helena está dialogando com uma pessoa morta:

- Quer me dar um cigarro? Ultimamente, você não fumava, mas fora fumante inveterado. Que alma levou para a eternidade? A de antes ou a de depois?

A simulação de um diálogo em que pergunta ao pai "Que alma levou a eternidade?" mostra que o narrador-personagem imagina um encontro com seu pai. Utilizar-se do caráter imaginativo é um recurso recorrente nos gêneros literários. Apesar de o gênero cronístico possuir em suas bases as características de gênero jornalístico, seu hibridismo permite que recursos de gêneros literários sejam incluídos em sua construção. Portanto, a crônica não precisa ser construída necessariamente com base em aspectos noticiosos para que seja caracterizada como gênero cronístico.

Em relação à temática que diz respeito à morte, o narrador menciona em um dos parágrafos ser comum que as pessoas passem pela sua vida rapidamente, e que, 
depois, acabem indo embora: "Creio que vivi toda a minha vida numa espécie de plataforma de estação, à espera de transitório viajantes...”.

Comparando-se a uma plataforma de trem por onde as pessoas passam diariamente, o narrador informa como a morte é um tema recorrente em sua vida. A frase citada no parágrafo anterior, à primeira vista, não tem sentido lógico, a não ser no contexto desta crônica. No entanto, após leitura minuciosa de sua obra Sombra Azul e Carneiro Branco, constata-se que este é o primeiro indício de que a morte será uma constante em sua produção. Esta menção, portanto, não foi despretensiosa. Um leitor atento da obra ou mesmo das crônicas quando eram publicadas diariamente nos jornais, ao ler uma afirmação dessas, já era capaz de fazer uma relação com as próximas temáticas a serem exploradas.

Toda a crônica é escrita por meio de um diálogo imaginário. E o narrador, em certo ponto, também atesta, claramente, que está imaginando toda aquela situação: “(...) Eu, na casa fechada, recriando-o, recebendo, à distância, a luz que ele emanava. Reconstituía suas grandes passadas, sua voz que fazia vibrar os cristais da étagère". (grifo nosso).

Esse recurso de alucinação é observado por Fernando Cohen (2005) em seu estudo sobre as crônicas de memória de Nelson Rodrigues. Ele cita uma observação de Adélia Bezerra de Meneses que será reproduzida para elucidar a questão da imaginação no processo de composição desta crônica de Helena Silveira: ${ }^{13}$

Não é o dado bruto que importa, mas sua transposição para o papel, e sua necessária transformação, quando entram os recursos estilísticos, a metáfora, a metonímia, o símbolo, a alegoria, quando atuam os processos de elaboração poética de condensação e deslocamento [...]. 
A memória é apenas matéria-prima de um processo de mimese. (MENESES, 1995 apud COHEN, 2005, p. 22).

A afirmação acima reflete o que, necessariamente, deve ser observado na análise de um texto de memória. Não se trata do fato rememorado em si, mas sim da forma pela qual essa memória é relatada. Devem ser considerados os recursos pertencentes à língua, ao gênero e, até, à mídia em que será veiculada tal narração. Neste estudo, esses são os fatores primordiais a serem analisados nas crônicas, pois será, justamente, pela caracterização desses conceitos que se objetiva, ao final, destacar a relação da autora com a temática da morte em suas crônicas de memória.

Logo no início da crônica, como já foi explicitado, fica claro que o narradorpersonagem conversando com o pai morto. No entanto, fica claro apenas posteriormente que seu pai, neste momento, é inalcançável e que toda a narrativa é fruto de sua imaginação. Seguem abaixo algumas menções em que este fator é exposto:

Ele, dono da luz, sempre partindo, sempre se desenhando num horizonte, que se renovava em minha imaginação e me era vedado. Eu, na casa fechada, recriando-o, recebendo à distância, a luz que ele emanava. Reconstituía suas grandes passadas, sua voz que fazia vibrar os cristais da étagère. (grifo nosso).

Trata-se de um parágrafo inteiro repleto de marcas de imaginação. A primeira menção expõe que a imagem do pai se formava na imaginação do narrador, mas que sua presença era proibida pelo motivo, evidente, de estar morto. Em seguida, o narrador afirma estar dentro de casa apenas recriando-o, em sua mente, e 
reconstituindo as suas passadas dentro da casa. É um momento em que a imaginação e o fantasioso dominam a crônica de memórias.

\subsubsection{Foco narrativo}

A crônica "Encontro com meu pai" apresenta possuir um narrador-personagem logo no seu título, quando expõe "Encontro com meu pai" por meio do pronome pessoal "meu.

É justamente o que ocorre. Composta pelo "eu" que participa da narrativa, a crônica destaca um narrador que vivencia o que está sendo narrado, que participa da narração como personagem.

De acordo com os aspectos expostos na fundamentação, o nome dado por Todorov (1970) a esse narrador é narrador-personagem. Em primeira pessoa, esse narrador traz maior complexidade à narrativa:

A narrativa na primeira pessoa não explicita a imagem de seu narrador, mas, ao contrário, torna-a mais implícita ainda. E qualquer ensaio de explicação só pode levar a uma dissimulação cada vez mais perfeita do sujeito da enunciação; o discurso que se confessa discurso não faz mais que ocultar pudicamente sua propriedade de discurso. (TODOROV, 1970, p. 48).

Em relação ao foco narrativo, a existência de um narrador que é o mesmo que a personagem da narrativa leva o leitor a um ponto de vista extremamente direcionado. Toda a informação que a ele é contada será, sempre, por meio de um único ponto de 
vista. Portanto, aqui, tem-se o relato de acontecimentos segundo apenas um determinado ponto de vista. E esse é, justamente, o do narrador-personagem.

Além de direcionar o leitor para o seu ponto de vista em relação a um determinado acontecimento, o narrador-personagem também manipula o leitor no tocante às interpretações de acontecimentos distintos. A manipulação ocorre por meio de metáforas; o narrador-personagem tenta e, por vezes, realmente consegue influenciar as interpretações dos fatos de maneira exagerada ou não.

É exatamente o que ocorre nesta crônica. Por meio de metáforas, o narradorpersonagem guia o leitor para o que ele quer mostrar sobre o pai que morreu, o que fica evidente no trecho a seguir:

Eu, na casa fechada, recriando-o, recebendo, à distância, a luz que ele emanava. Reconstituía suas grandes passadas, sua voz que fazia vibrar os cristais da étagère. (grifo nosso).

Uma das características literárias muito presentes na crônica é a metáfora. É um recurso típico das narrativas literárias que o gênero cronístico resgata pela sua característica híbrida e pela necessidade que o gênero tem de, ao mesmo tempo em que está perto do noticioso, se aproximar do literário. Portanto, a crônica explora, e muito, essa figura de linguagem.

Há um parágrafo repleto de metáforas que reflete exatamente o que o narrador pensava sobre seu pai:

Outro dia, disse a alguém que você nunca fora um pai de chinelas e de cadeira de balanço, e logo me senti plena de culpa. Não é muito melhor ter possuído um pai que era "o homem que andava na rua", espécie de marinheiro, para mim embarcado na nau de todas as aventuras e ainda carregando astros nos olhos? (grifo nosso). 
Ter "um pai de chinelas e de cadeira de balanço" é uma alusão a um pai convencional. O que não é o caso, uma vez que o narrador afirma que o pai era uma "espécie de marinheiro" e "carregando astros nos olhos". Além de serem metáforas, essas frases também podem ser consideradas marcadores lingüísticos que representam a cultura oral (RIBEIRO, 2007, p. 97). São frases que representam visões de mundo de uma determinada comunidade, principalmente no caso da frase "um pai de chinelas e de cadeira de balanço".

Além de o narrador-personagem ser protagonista de suas próprias lembranças, ou seja, de suas memórias, ele também atua como comentarista na narrativa.

"Creio que vivi toda a minha vida numa espécie de plataforma de estação, à espera de transitórios viajantes..." Esta fala já representou outro aspecto referente à temática citado anteriormente, e além de também representar uma análise do narrador quanto à sua situação na vida em que está.

\subsubsection{Tipologia da linguagem jornalística e cronística}

Em relação à tipologia jornalística e cronística, as crônicas não têm necessariamente a forma de pirâmide invertida como ocorre nas notícias veiculadas em jornais. Porém, um recurso muito utilizado pelos cronistas é chamar a atenção do leitor logo nos primeiros parágrafos com alguma informação ou comentário que desperte a curiosidade do leitor (VIVALDI, 1979, p. 138). 
No caso da crônica em questão, o narrador faz uso desse recurso quando introduz no suposto diálogo com seu pai a pergunta: "Que alma levou para a eternidade? A de antes ou a de depois?". É fato, aqui, que esta pergunta causa estranhamento no leitor e que o faz pensar se ele está entendendo realmente que há um diálogo com um morto. E, logo depois, o pai responde ter levado para o Além com letra maiúscula - um pouco de todas. "- Você é que não fumava! Quanto a essa questão de alma, creio que levei para o Além um pouco de todas que tive".

A presença do coloquial também é evidente e faz com que a crônica transgrida sua característica de focar o cotidiano e a aproxima do literário, diferenciando-se do texto noticioso.

Em "Encontro com meu pai" há uma série de reproduções de diálogos que refletem o coloquialismo tão comuns nas crônicas, principalmente nas crônicas de Helena Silveira, como poderá ser visto nas análises das demais crônicas. Por enquanto, citam-se alguns exemplos desta crônica que ilustram a presença do coloquial:

- Quer me dar um cigarro? Ultimamente, você não fumava, mas fora fumante inveterado. Que alma levou para a eternidade?

$[\ldots]$

- Você é que não fumava! Quanto a essa questão de alma, creio que levei para o Além um pouco de todas que tive.

Apesar de amá-lo tanto, creio que sempre tive um pouco medo de você. Não ousaria fumar na sua frente. Agora, parece que tudo mudou; nosso encontro é mais sem subterfúgios. 
- Marca temporal

Outra marca cronística é a questão da temporalidade. Ao longo de toda a crônica, o narrador vai e vem no tempo por meio de marcas temporais.

Quis justificar-me, porque, no momento como anteriormente, a sua condenação seria intolerável.

$[\cdots]$

Agora, parece que tudo mudou;

$[\ldots]$

Baixei meu rosto e me senti inundada pela flama, espécie de infernozinho particular dentro da noite. Não fora assim sempre? [...] (grifo nosso).

Essas marcas temporais presentes nesta crônica são marcas sutis que remetem a um passado, o qual, porém, fica no campo do subjetivo, não sendo explorado ao longo da crônica. 


\subsubsection{Crônica: O príncipe Sisido}

\subsubsection{Temática}

Esta crônica representa uma homenagem de Helena em comemoração aos 50 anos da imigração japonesa no Brasil. Apesar de ter caráter poético desde o início, manifestando suas lembranças de um criado que a ensinara a gostar da natureza, Helena vincula essa experiência ao privilégio de conhecer um desses imigrantes japoneses. É com base em sua experiência que a autora homenageia os imigrantes japoneses.

Considerando o contexto em que a crônica foi escrita - comemorava-se o qüinquagésimo aniversário da vinda dos imigrantes japoneses para o Brasil -, Helena aproveitou o contexto da comemoração para expor sua experiência pessoal em relação a um desses imigrantes, conforme pode-se ler na reprodução do primeiro parágrafo da crônica, em que fica clara a sua gratidão ao amigo, e no último parágrafo, em que ela manifesta o acontecimento da imigração:

Ele me ensinou as flores, as folhas, os arbustos, as manhãs, as tardes, os ventos e, sobretudo, o jardim. Antes dele, havia as salas altas de piso encerado, a cadeirinha dourada em forma de harpa, o piano onde minha irmã cantava o Reviens, veux-tu e outra irmã acordava para o romântico das sonatas. Lá fora, havia um vago mundo vegetal que me encantava. Foi ele que estabeleceu o primeiro nexo desse mundo com a criança que eu era.

$[\ldots]$ 
Com a cidade toda cheia dessa brava gente que imigrou para lá vão cinqüenta anos, penso em meu amigo Sisido. Na verdade, depois que vieram para cá os japoneses, nós amamos um pouco mais, talvez, a terra marrom que Deus nos deu e toda a vegetação que dela podemos fazer brotar... Eles ensinaram muito do mundo mágico das plantas aos tristes homens urbanos, e fizeram de nossas caboclas goiabas pequenas luas impressionistas.

A crônica é um gênero que permite essa postura que Helena Silveira expõe em sua crônica: uma exposição pessoal num veículo de comunicação diário - o jornal entrelaçada a um fator social do período. Tal singularidade faz da crônica um gênero extremamente ligado ao tempo e à memória, exatamente o que se tem nesta crônica de Helena Silveira.

Davi Arrigucci Jr. ${ }^{14}$ confirma essa teoria sobre a crônica:

Um leitor atual pode não se dar conta desse vínculo de origem que faz dela uma forma do tempo e da memória, um meio de representação temporal dos eventos passados, um registro da vida escoada. Mas a crônica sempre tece a continuidade do gesto humano na tela do tempo. (ARRIGUCCI, 1999 apud SOUSA, 2005, p. 153).

A competência de conseguir produzir uma crônica além da visão do cotidiano, seja mesclando fatos da memória pessoal às do cotidiano ou, simplesmente, poetizando em prosa o que o dia-a-dia lhe apresenta, é o que se espera de um cronista. Como afirma Eduardo Portella: 
[...] aquele que se apega à notícia, que não é capaz de construir uma existência além do cotidiano, este se perde no dia-a-dia e tem apenas a vida efêmera do jornal. Os outros, esses transcendem e permanecem. (PORTELLA, 1999 apud SOUSA, 2005, p. 154).

\subsubsection{Tipologia da linguagem jornalística e cronística}

A crônica "O príncipe Sisido", assim como a crônica anterior, é uma rememoração de fatos vividos na infância que o narrador traz à tona em sua vida adulta e que ainda o influenciam.

Da mesma forma como foi feito na crônica "A viagem e o beijo", aqui será feita uma análise minuciosa de suas características temporais com o objetivo de compreender e elucidar a articulação temporal que existe em seu discurso.

Os conceitos sobre temporalidade contidos na obra de Gérard Genette não serão aqui citados novamente, como foram feitos na análise da crônica anterior, a fim de evitar repetições desnecessárias. No entanto, eles serão a todo momento considerados como base principal desta análise.

A primeira etapa fundamental para o estudo da temporalidade de uma narrativa é localizar as posições temporais presentes na crônica.

A crônica gira em torno de três posições temporais. Ela tem início no tempo passado com a rememoração de lembranças da infância. Logo no primeiro parágrafo há esta exposição: "Ele me ensinou as flores, as folhas, os arbustos, as manhãs, as tardes, os ventos e, sobretudo, o jardim". 
Esse é o período que domina boa parte da crônica. O narrador descreve as lembranças de um determinado período da sua vida graças ao aprendizado que teve de outra pessoa, como é o caso da personagem Sisido. Esse primeiro período pode ser considerado a narrativa primeira, aquela pela qual as outras narrativas serão construídas e que, de certa forma, possuirão dependência.

Logo no primeiro parágrafo há uma transposição temporal quando o narrador faz menção à sua vida antes de ter conhecido a personagem Sisido. Trata-se, aqui, de um retorno ao passado anterior ao que primeiro citado. Esse é o único momento em que ocorre a exposição de um passado anterior ao que move a narrativa:

Antes dele, havia as salas altas de piso encerado, a cadeirinha dourada em forma de harpa, o piano onde minha irmã cantava o Reviens, veux-tu e outra irmã acordava para o romântico das sonatas. Lá fora, havia um vago mundo vegetal que me encantava.

Mas, logo em seguida, o tempo da narrativa primeira é retomado: "Foi ele que estabeleceu o primeiro nexo desse mundo com a criança que eu era".

O outro tempo contido na narrativa é o presente, mencionado em poucos momentos específicos:

Contudo, jamais vi alguém tão alvo de pele, os cabelos negros e lisos, um rosado sadio nas faces.

$[\ldots]$

Hoje penso que, se nesses momentos atentasse para suas longas mãos, veria partir delas flechas de luz, a exemplo do que se vê na imagem dos bem-aventurados. 
Esse exercício de voltar ao presente serviu como uma maneira de completar as descrições que o narrador faz do passado. Trata-se de um complemento às informações principais da narrativa.

Desmembrar a narrativa, contemplando os tempos que a compõem, fornece subsídios para a compreensão da presença das anacronias e de suas funções.

Logo no primeiro parágrafo há o recurso de uma analepse necessária para a distinção de modos de vida diferentes em tempos diferentes.

Ele me ensinou as flores, as folhas, os arbustos, as manhãs, as tardes, os ventos e, sobretudo, o jardim. Antes dele, havia as salas altas de piso encerado, a cadeirinha dourada em forma de harpa, o piano onde minha irmã cantava o Reviens, veux-tu e outra irmã acordava para o romântico das sonatas. (grifo nosso).

Trata-se de uma analepse interna completiva, o que significa que o narrador se utiliza de um recurso que complementa as informações de vida daquela criança. Sem tal analepse, a narrativa seria perfeitamente possível. No entanto, a analepse permitiu a evocação de uma situação anterior e também reforçou a importância da presença da personagem Sisido na vida daquela criança.

É preciso observar que há dois segmentos nesse primeiro parágrafo. O primeiro segmento dá início à crônica: "Ele me ensinou as flores, as folhas, os arbustos, as manhãs, as tardes, os ventos, e, sobretudo, o jardim". O segmento seguinte é composto pela analepse, cuja característica é retomar uma situação ou um fato anterior. Assim, temos dois tempos distintos neste período: o passado e uma situação anterior ao passado. Nesta relação temporal exercida pela analepse há uma situação de subordinação do segundo segmento em relação ao primeiro. 
Em seguida há o retorno à posição inicial por meio de um chamado de Sisido à criança sem que haja subordinação desse segmento a outro.

Já no parágrafo seguinte, há uma mudança brusca de posição temporal quando surge o segmento "Contudo, jamais vi alguém tão alvo de pele, os cabelos negros e lisos, um rosado sadio nas faces". Esse segmento, iniciado pela conjunção adversativa "contudo", estabelece uma relação intertextual, como afirma Bechara (2003), com o segmento anterior, de forma que haja uma migração do discurso que até então estava focado no tempo passado para o tempo presente, sem que houvesse qualquer alteração na narrativa anterior.

Mais adiante, outra intervenção temporal que quebra a seqüência da narrativa está presente neste segmento: "Hoje penso que, se nesses momentos atentasse para suas longas mãos, veria partir delas flechas de luz, a exemplo do que se vê na imagem dos bem-aventurados". Aqui, há uma antecipação no presente de um fato que poderia ter ocorrido. Esse recurso é possível graças à prolepse que, normalmente, é menos utilizada que a analepse.

A narrativa tem seqüência no tempo passado da mesma forma como ela teve início. As presenças das anacronias permitem um contraste entre a ordem dos fatos na narrativa, recurso fundamental para a compreensão desses fatos e também uma quebra da linearidade da leitura. 


\subsubsection{Articulação temporal da narrativa}

O tempo de narração é o primeiro a ser considerado. Neste aspecto é determinado o tempo presente na instância da narrativa.

A crônica "O príncipe Sisido" é uma narrativa em que o narrador relata algumas lembranças de sua infância. Elaborada em quase toda a sua extensão por verbos no pretérito, o tempo de narração da crônica pode ser determinado como ulterior, conforme o segmento abaixo:

Ele me ensinou as flores, as folhas, os arbustos, as manhãs, as tardes, os ventos e, sobretudo, o jardim. Antes dele, havia as salas altas de piso encerado, a cadeirinha dourada em forma de harpa, o piano onde minha irmã cantava o Reviens, veux-tu e outra irmã acordava para o romântico das sonatas. Lá fora, havia um vago mundo vegetal que me encantava. Foi ele que estabeleceu o primeiro nexo desse mundo com a criança que eu era.

No entanto, nesta crônica, há também uma situação exemplificada por Genette em sua teoria. Fala-se, aqui, de um efeito que traz convergência entre o passado - no caso, a diegese - e o presente - o discurso da narrativa. Esse efeito é a menção de determinados segmentos no presente, como é o caso a seguir: "Hoje penso que, se nesses momentos atentasse para suas longas mãos, veria partir delas flechas de luz, a exemplo do que se vê na imagem dos bem-aventurados".

Apesar de a narrativa ser quase toda construída referindo-se à situações do passado, esta ocorrência garante um retorno da narrativa ao presente e um esbarro com o tempo da narrativa. É importante notar que se trata aqui de uma breve 
referência ao presente, pois para caracterizarmos a narrativa como ulterior, Genette explica que é preciso que o tempo referente à narração se supere ao tempo da história.

\section{- Anisocronias - efeitos de ritmo}

Outro recurso um tanto presente nesta crônica são as anisocronias que, por meio das elipses, permitem que a narrativa tenha efeitos de ritmo. Esses efeitos de ritmo são os recursos que concedem à narrativa uma circulação entre os tempos, permitindo que o tempo da diegese seja maior do que o tempo da narrativa propriamente dito. Genette (1995) representa esta situação com a fórmula TN < TH.

Há elipse no segmento: "Deixou-nos mais tarde para ser chofer". Aqui, há nitidamente a presença de uma elipse implícita, pelo fato de não estar evidente em que tempo a personagem Sisido deixou de ser jardineiro para se tornar chofer.

O mesmo ocorre no segmento: "Passaram-se os dias e, certa manhã, comunicaram-nos que Sisido fora recolhido, muito mal, a uma enfermaria da Santa Casa". Aqui também está implícita a passagem dos dias.

Mas há também a presença de elipses explícitas: "Com a cidade toda cheia dessa brava gente que imigrou para lá vão cinqüenta anos, penso em meu amigo Sisido". Nesse segmento está explícito que o narrador diz fazer cinqüenta anos da imigração japonesa para o Brasil.

As elipses na crônica providenciam o ritmo da narrativa. Vê-se o registro de que o tempo da narrativa é nulo, mas o tempo da diegese pode ser infinito. 


\subsubsection{Foco narrativo}

Na crônica "O príncipe Sisido" há um narrador-personagem que rememora um período da sua infância. Aqui, como ocorreu na crônica "A viagem e o beijo", é importante considerar que é uma rememoração, mas que há um aspecto fantasioso quando a questão temporal é tão evidente.

Nesta crônica, a questão fantasiosa se apresenta em menor grau quando comparada à crônica "A viagem e o beijo". Isso se justifica porque, neste caso, o narrador-personagem não é a personagem principal da crônica. Aqui, a personagem principal é Sisido, um japonês que foi trabalhar na casa do narrador.

Além disso, o narrador rememora fatos pontuais decorridos da presença de Sisido. Isso faz que menos metáforas sejam exploradas, quando comparada à outra crônica, cujas metáforas eram abundantes.

Mas, é claro que elas existem e reforçam a questão do narrador-personagem, que emite a sua opinião, conforme trecho abaixo:

Hoje penso que, se nesses momentos atentasse para suas longas mãos, veria partir delas flechas de luz, a exemplo do que se vê na imagem dos bem-aventurados. Era uma espécie de Francisco de Assis nipão, sem tonsuras, mas todo atento à voz dos pássaros, ao passar do vento nas touceiras dos bambus, ao jeito peculiar que tinha o sol de inverno de filtrar sua luz pela folhagem do jardim. (grifo nosso).

Nos trechos grifados há intenção por parte do narrador-personagem de convencer o leitor sobre a idéia que tinha a respeito da personagem Sisido. 
Esse aspecto de persuasão é típico da crônica. Quando a voz do cronista deixa de ser impessoal e se inclui na redação, o texto se afasta das notícias de periódicos que tendem a ser imparciais - e se aproxima dos artigos de opinião e, neste caso, do gênero crônica.Trata-se de um aspecto específico desse gênero. 


\subsubsection{Crônica: Geografia da morte}

\subsubsection{Temática}

A crônica "Geografia da morte", como o próprio título, tem a morte como tema principal. Trata-se de uma narrativa a respeito da questão dos cemitérios nas metrópoles. O inchaço da cidade ocorrido por conta das imigrações e as epidemias de doenças como a febre amarela e a cólera trouxeram o problema da falta de espaço para a composição dos cemitérios nas grandes cidades. Em torno dessa questão, o narrador trata do tema da morte como uma questão que tem tomado proporções diferentes ao longo do tempo.

O narrador cita o período do Romantismo - embora o período não tenha sido mencionado explicitamente -, porém quando o narrador diz no quarto parágrafo "Antigamente, o que havia era o Romantismo (...)" em que o termo "Romantismo" aparece em caixa alta, supõe-se que ele esteja se referindo ao período literário do início do século XIX. Além dessa observação sobre a inicial do termo, tem-se que o narrador menciona haver uma "atitude romântica perante a vida e as suas conseqüências".

Ele compara a época do Romantismo com a atual, no período em que está inserido, meados do século $X X$. No primeiro período, a morte era vista como uma etapa romântica da vida. Já no século $X X$, a morte estava sendo vista como um problema urbano. 
Nota-se que a morte é referida em caixa alta diversas vezes, pois ela é tratada como a personagem principal do texto. No segundo parágrafo, a morte começa a ser mencionada com essa característica:

Os cemitérios no Brasil, a princípio eram coisas pequenas, tanto que podiam caber no recesso das igrejas: depois, veio febre amarela, e cólera, e os corpos mortos tiveram que transbordar desses recintos sagrados, e a cerimônia do enterramento de certo modo profanou-se. Este foi o primeiro golpe que a Morte padeceu entre nós, no seu caráter de coisa transcendente, sobrenatural, fora da vida. (grifo nosso).

Neste trecho a "Morte padeceu"; a morte como personagem que sofrera com a chegada das novas epidemias. É o momento em que ela foi profanada, ou seja, perdeu seu caráter puro e divino. Ela passou a ser tratada como uma questão meramente rotineira. E a discussão sobre a cremação dos corpos passou a ser pauta das grandes cidades, como uma evolução entre a relação da vida e da morte.

\subsubsection{Tipologia da linguagem jornalística e cronística}

\subsubsection{Articulação temporal da narrativa}

A crônica "Geografia da morte", diferentemente das demais crônicas analisadas, não é uma rememoração da infância. Trata-se de uma crônica que discute um problema contemporâneo das grandes cidades. 
Com o objetivo de retratar a nova percepção dos indivíduos diante da morte, o narrador a situa temporalmente ao tempo de Joana D'Arc, mencionando que atear fogo às vestes poderia se tornar um ato valorizado entre os indivíduos.

Logo mais, a situa no período do Romantismo, como exposto anteriormente. E, depois, a traz para o período contemporâneo. É importante, agora, por meio dos conceitos de Genette, situar a crônica temporalmente, tendo como referência essa movimentação do narrador.

A crônica tem início com a manifestação do narrador de sua ignorância das discussões atuais em relação ao assunto que rememorará. Ele, portanto, conta o que soube há algum tempo, mas não se arrisca a mencionar como anda a discussão.

Um típico recurso das narrativas de memórias é a anacronia, como já evidenciado em outras crônicas. Como um jogo de vai-e-vem entre o passado e o presente, há na crônica "Geografia da morte" a presença constante, principalmente, de analepses. Por meio de uma analepse, o autor situa sua narrativa no passado: "Faz algum tempo, a Câmara tomou conhecimento do problema e a dúvida surgiu: crema ou não crema?". (grifo nosso).

E o recurso das analepses se repete várias vezes. Nota-se ocorrer uma oscilação temporal entre o antes e o agora: "Antigamente, o que havia era o Romantismo, era a atitude romântica perante a vida e as suas conseqüências. E, nesse sentido, a Morte era cantada. Agora, outros fatores aparecem [...]".(grifo nosso).

A crônica "Geografia da morte", além de ser caracterizada pelo memorialismo é também uma crônica noticiosa. Ela traz o aspecto noticioso - uma característica da crônica (VAN DICK, 1970) - e histórico no decorrer de toda a narrativa, com o objetivo de entrelaçar a mudança no conceito de morte com as mudanças sociais, religiosas e econômicas da cidade. 
Logo no primeiro parágrafo, o narrador explicita uma notícia para ambientar o leitor quanto à gravidade das situações dos cemitérios:

Leio em manchetes de vespertino: "Teme-se morrer na Capital: nos cemitérios não há vagas". Se viver é difícil em São Paulo, morrer não é menos. Há até câmbio negro de campas, e todo um escuso negócio a florescer junto às tumbas, como as boninas dos poetas ligados às metafísicas indagações do "se eu morresse amanhã?".

Além da notícia de que nos cemitérios não há vagas, o narrador complementa dizendo que, já naquela época, viver em São Paulo não era fácil e que morrer também não o era.

Já no quinto parágrafo, há outra referência histórica que complementa a compreensão da narrativa. O narrador resgata o período do Romantismo para mencionar como a morte era vista: "Antigamente, o que havia era o Romantismo, era a atitude romântica perante a vida e as suas conseqüências. E, nesse sentido, a Morte era cantada".

Há, também, uma menção a Baudelaire ${ }^{15}$ remetendo a questão da cremação em um poema em que descreve o encontro de um corpo em decomposição e alerta à sua amada que, um dia, será como aquela que está apodrecendo.

E não é preciso ser poeta para concluir-se que mais vale arder que apodrecer. Melhor ser cinza, obtida mais ou menos sinteticamente, à custa de fogo purificador, que esperar pelo trabalho meticuloso dos vermes sobre aquilo que foi corpo, mas agora é apenas inspiração de Baudelaire, vil carniça, charogne desalentada.

\footnotetext{
${ }^{15}$ Poema: Uma carniça conforme anexo 2.
} 
Essa técnica é característica muito comum do gênero cronístico: fazer menção a autores, comparações que explicitem melhor o tema narrado.

Outra técnica tipicamente cronística é a adoção de reticências. Na verdade, é uma referência aos romances-folhetins que, ao final de cada dia, expunham as reticências com o objetivo de indicar ao leitor que a narrativa continuaria na próxima edição. O gênero cronístico adotou essa técnica, mas com a intenção de proporcionar ao leitor certa reflexão no tocante ao assunto.

Um recurso muito explorado pelo gênero cronístico é o caráter opinativo. No discurso noticioso não é usual emitir uma opinião. Já a crônica faz uso desse recurso com o objetivo de aproximar o leitor da narrativa e também de persuadi-lo.

Mas, em minha ignorância, suponho que todos aqueles simbólicos preceitos bíblicos sofrem interpretações nem sempre exatas. Então, quem morre por acidente, em incêndio, não encontra morada para o espírito? E Santa Joana? E tantos e tantos outros mártires católicos?

\subsubsection{Foco narrativo}

A crônica "Geografia da morte" possui um ponto de vista instável ao longo de sua narrativa, diferentemente das crônicas que foram analisadas anteriormente. Isso significa que o ponto de vista muda ao longo da crônica. Segundo Genette (1995), um determinado ponto de vista pode ser aplicado em um instante muito breve da obra. Portanto, essa é uma técnica que pode ser usada ao longo de uma narrativa: mudar o ponto de vista de acordo com o desenrolar da narrativa. 
É exatamente o que ocorre nesta crônica. O narrador a inicia manifestando-se desconhecedor da cremação dos cadáveres, mas, logo em seguida, abstém-se de participar da narrativa como narrador-personagem e passa a ser um narrador onisciente, o que vai acontecer somente no parágrafo seguinte de modo muito discreto. Abaixo, é transcrito o primeiro parágrafo, com o objetivo de elucidar essa passagem do narrador-personagem para um narrador onisciente:

Não sei em que pé andam as discussões em torno da cremação de cadáveres. Faz algum tempo, a Câmara tomou conhecimento do problema e a dúvida surgiu: crema ou não crema? A cidade dos vivos cresce e, obviamente, prejudica a dos mortos, e estes impedem o trânsito... Leio em manchetes de vespertino [...]

Os cemitérios no Brasil, a princípio eram coisas pequenas, tanto que podiam caber no recesso das igrejas: depois, veio febre amarela, e cólera, e os corpos mortos tiveram que transbordar desses recintos sagrados.

Boa parte do restante da crônica é narrada em terceira pessoa. Conforme exposto na fundamentação teórica por Dal Farra (1978), a mudança de "pessoa" na narrativa não reflete a presença ou o distanciamento do narrador. Ambas, narrativas em primeira ou em terceira pessoa, possuem um narrador que atua com máscara do autor.

É o que acontece na crônica "Geografia da morte". O narrador distancia-se dos fatos como narrador-onisciente não deixa de emitir sua opinião e de persuadir o leitor com as questões relativas ao problema de aglomeração das grandes cidades. Vê-se que o narrador está tão como foi constatado nas crônicas anteriormente analisadas. 


\section{CONSIDERAÇÕES FINAIS}

\subsection{As visões sobre a morte nas crônicas de Helena Silveira}

Foi descrita no primeiro capítulo a propagação da literatura nos periódicos da França ao Brasil. E de que forma a presença da literatura nos periódicos contribuiu com o surgimento do gênero cronístico e com a sua popularização, aspectos que foram considerados como base para a análise da obra de Helena Silveira.

Com base na fundamentação teórica foram analisadas quatro crônicas da obra Sombra Azul e Carneiro Branco de Helena Silveira, selecionadas a partir da temática referente à morte e, também, considerando o aspecto diversificado do ponto de vista em relação à temática explorada.

Sobre a questão do ponto de vista selecionado pelo autor-implícito e sua relação com a temática da morte, pode-se afirmar que, comparando-se a análise realizada nas quatro crônicas aqui estudadas, constata-se que o foco narrativo mesmo com temáticas iguais é muito diferente. Cada crônica explora um aspecto e o narrador se posiciona sob uma determinada perspectiva.

A escolha do ponto de vista feita pelo autor-implícito foi determinada de acordo com a sua intenção de expor a temática.

$\mathrm{Na}$ primeira crônica analisada, "Encontro com meu pai", há um narradorpersonagem, protagonista de suas próprias lembranças, de suas memórias, e que também atua como comentarista na narrativa. Nesta crônica, a questão da morte está vinculada à perda paterna, o que faz o narrador-personagem expor um fantasioso encontro com o pai. Sem poupar a imaginação, o narrador explora o caráter místico da 
morte e destrincha um encontro com direito a um diálogo com o falecido e rememorações dentro da própria narrativa fantasiosa.

Na segunda crônica analisada, "A viagem e o beijo", a relação do narradorpersonagem com a morte é diferente da exposta na crônica anterior. Aqui há a rememoração de um fato ocorrido numa longínqua infância e que, por isso, faz que o foco narrativo daquele narrador-personagem esteja acoplado toda uma vida que se passara. O narrador-personagem tenta expor a morte da mãe como um acontecimento que o perseguira por toda a vida e o qual ainda não aceitara. No entanto, também faz uso do caráter imaginativo quando descreve o encontro com a mãe morta. Nesta crônica, a relação do narrador-personagem com a morte é de indignação.

Na análise da terceira crônica, "O príncipe Sisido", a morte, para o narradorpersonagem, está vinculada a um momento de sua infância e também a um fato histórico do país - a imigração japonesa. Vinculando os dois fatos, o narradorpersonagem apresenta sua aceitação diante da morte daquele que teria sido o amigo adulto de uma criança, com quem teve uma relação que se mostrou repleta de respeito e admiração de ambas as partes. Nesta crônica, a morte é encarada pelo narradorpersonagem como uma oportunidade de reflexão a respeito de uma pequena etapa de sua vida.

Já a quarta crônica analisada, "Geografia da morte", traz um narrador que, algumas vezes, aparece como narrador-personagem e que, em outras, aparece como narrador onisciente. Este fato já a diferencia das demais crônicas analisadas. No entanto, o aspecto que mais a difere das outras é o foco narrativo adotado pelo narrador. Aqui, o narrador expõe a questão da morte como um problema social e deslancha um pouco de sua evolução, concorrendo com a própria evolução humana. A característica trágica é deixada totalmente de lado, e a morte se torna um elemento 
que faz parte da vida e que, portanto, ao ser ignorada, traz prejuízos inclusive sociais e, conseqüentemente, espaciais.

Traçado um perfil histórico e conceitual dos gêneros cronístico e memorialístico, feita análise minuciosa com base na fundamentação teórica descrita o confronto entre os possíveis focos narrativos sobre a morte contidos nas crônicas de Helena Silveira traz uma amostra da possível abordagem da relação que Helena Silveira tinha com tal temática.

Esta análise, com base em tal temática, se justifica pela constância em sua seleção contida na obra Sombra Azul e Carneiro Branco. Trata-se da temática mais presente em toda a sua obra. Diante desse fato, julgou-se necessária a elaboração de uma análise que pudesse traçar um perfil da relação da autora com a morte. 


\section{REFERÊNCIAS BIBLIOGRÁFICAS}

AGUIAR E SILVA, Vitor Manuel de. Gêneros literários. In: Teoria da literatura. 4. ed. Coimbra: Editora, 1975, p. 203-226.

A poética. In: Teoria e metodologia literárias. Lisboa: Universidade Aberta, 1990, p. 14-16.

BAKHTIN, Mikhail. Os Gêneros do discurso. In: Estética da criação verbal. São Paulo: Edunesp, 1999.

BECHARA, Evanildo. Moderna gramática portuguesa. 37. edição, revista e ampliada. Rio de Janeiro: Lucerna, 2003.

BERTRAND, Denis. Caminhos da semiótica literária. Bauru: Edusc, 2003.

BOSI, Alfredo. A literatura brasileira. São Paulo: Cultrix, 1966.

CANDIDO, Antonio, et. al. A crônica: o gênero, sua fixação e suas transformações no Brasil. Rio de Janeiro: Fundação Casa de Rui Barbosa, 1992.

CHALHOUB, Sidney et al. História em cousas miúdas. São Paulo: Unicamp, 2005. 
COUTINHO, Afrânio. Introdução à literatura no Brasil. Rio de Janeiro: São José, 1964.

A literatura no Brasil. Rio de Janeiro: Sul Americana S.A., 1971.

(org.) Raul Pompéia: - Crônicas I. Rio de Janeiro: Civilização Brasileira, 1982.

COHEN, Fernando. Crônicas da memória: um estudo de "A menina sem estrela", de Nelson Rodrigues. 2005. 103 f. Dissertação (Mestrado em Literatura Brasileira). Faculdade de Filosofia Letras e Ciências Humanas da Universidade de São Paulo, São Paulo, 2005.

DAL FARRA, Maria Lúcia. O narrador ensimesmado (O foco narrativo em Virgílio Ferreira). São Paulo: Ática, 1978.

FÁVERO, Afonso Henrique. Aspectos do memorialismo brasileiro. 1999. 370 f. Tese (Doutorado em Literatura Brasileira). Faculdade de Filosofia Letras e Ciências Humanas da Universidade de São Paulo (FFLCH-USP), São Paulo, 1999.

GENETTE, Gerard. Discurso da narrativa. Lisboa: Veja Universidade, 1995. 
ISER, Wolfgang. O conceito de leitor implícito In: 0 ato da leitura: uma teoria do efeito estético. Trad. Johanes Kretcmer. São Paulo: 34, 1999.

LEITE, Ligia Chiappini Moraes. O foco narrativo. São Paulo: Ática, 1993.

MARTINS, Wilson. O modernismo: a literatura brasileira. São Paulo: Cultrix, 1969.

MEYER, Marlyse. Folhetim - uma história. São Paulo: Cia das Letras, 1996.

MORIN, Edgar. A articulação dos saberes In: Complexidade e transdisciplinaridade. Trad. Edgard de Assis Carvalho. Natal: UFRN, 1999, p. 27-53.

PEREIRA, Wellington. Crônica: a arte do útil e do fútil. Bahia: Calandra, 2004.

RIBEIRO, José Alcides. Industria cultural e gênese ficcional em Memórias de Um Sargento de Milícias. In: Gênese e Memória: Anais do Quarto Encontro Internacional de Pesquisadores do Manuscrito e de Edições. Org. Philippe Willemart. São Paulo: Annablume, Associação dos Pesquisadores do Manuscrito Literário, 1995, p. 321-328.

. O romance-folhetim francês e seu padrão narrativo. In: Imprensa e ficção no século XIX: Edgar Allan Poe e a Narrativa de Arthur Gordon Pym. São Paulo: Universidade Estadual Paulista, 1996, p. 25-50. 
Ficção e imprensa no Brasil: os processos de criação de José de Alencar e de Joaquim Manuel de Macedo. In: Fragmentos de cultura. Goiânia: Universidade Católica de Goiás, v. 9, n.5, p. 1.081-1.092, set/out. 1999.

. Texto verbal e imagem visual em O Ateneu de Raul Pompéia: uma poética radical na ficção em jornais. In: Estudos - Humanidades - Revista da Universidade Católica de Goiás. Goiânia: Universidade Católica de Goiás, v. 28, n. 3, p. 371-392, mai./jun. 2001.

Transdisciplinaridade - Literatura brasileira e jornalismo - Jornal do Commercio. São Paulo: Fernando Bilah, 2007.

SERRA, Tânia Rebelo Costa. O escritor reabilitado. In: Joaquim Manuel de Macedo ou os dois Macedos: a luneta mágica do II Reinado. Rio de Janeiro: Fundação Biblioteca Nacional, 1994.

SILVEIRA, Helena. Sombra Azul e Carneiro Branco. São Paulo: Cultrix, 1960.

SODRÉ, Nelson Werneck. In: História da imprensa no Brasil. 4. ed. Rio de Janeiro: Mauad, 1999.

SALLES, Cecília de Almeida. Crítica genética: uma introdução. São Paulo: Educ, 1992.

SÁ, Jorge. A crônica. 6. ed. São Paulo: Ática, 2001. 
SOUSA, João Alberto de. Memória histórica sobre o Correio Paulistano. São Paulo: Rosenhain \& Meyer, 1904.

SOUSA, Sérgio Barbosa de. Marcas temporais e histórico-linguisticas na crônica Era bonito ser histérica, Nelson Rodrigues. In: A historiografia lingüística: rumos possíveis. São Paulo: Pulsar, Terras do Sonhar, 2005, p. 139-170.

THOMPSON, John B. Transmissão cultural e comunicação de massa: o desenvolvimento das indústrias da mídia. In: Ideologia e cultura moderna. Trad. Grupo de Estudos sobre eologia-Pontifícia Universidade Católica do Rio Grande do Sul (PUC-RS). Petrópolis: Vozes, p. 221-266.

TERROU, F. \& ALBERT, P. A industrialização e a democratização da imprensa do início do século XIX a 1871. In: História da imprensa. Trad. Edison Darci Heldt. São Paulo: Martins Fontes, 1990, p. 29-50.

TODOROV, Tzvetan. Estruturalismo e poética. São Paulo: Cultrix, 1970. . Poética da prosa. São Paulo: Martins Fontes, 2003.

VAN DIJK, Teun A. van La noticia como discurso: comprensión, estructura y producción de la información. Cidade: Paidós Comunicación, 1990.

VIVALDI, Gonzalo Martin. Gêneros periodísticos. Madrid: Paraninfo, 1979. 


\section{Outras fontes}

ANAN, Sylvia Tamie. Crônica da vida inteira: memórias da infância nas crônicas de Manuel Bandeira. São Paulo: Edusp, 2006.

PATRINI, Maria de Lourdes. Rubem Braga: um cronista de guerra e paz. São Paulo: Edusp, 1991.

RUGGERO, Niube. O olhar feminino nas crônicas de Maria Judite de Carvalho e Clarice Lispector. São Paulo: Edusp, 2000.

\section{Sites}

<www.cpdoc.fgv.br/nav_historia/htm/ano> 


\section{ANEXO A}

\section{Encontro com meu pai}

Achei natural que ele estivesse ali, à descida do ônibus; que em torno fosse a madrugada, São Paulo tendo tomado seus contornos românticos de garoa:

- Quer me dar um cigarro? Ultimamente, você não fumava, mas fora fumante inveterado. Que alma levou para a eternidade? A de antes ou a de depois?

Sorrindo, ele me estendeu a cigarreira aberta:

- Você é que não fumava! Quanto a essa questão de alma, creio que levei para o Além um pouco de todas que tive.

Quis justificar-me, porque, no momento como anteriormente, a sua condenação seria intolerável:

- Apesar de amá-lo tanto, creio que sempre tive um pouco medo de você. Não ousaria fumar na sua frente. Agora, parece que tudo mudou; nosso encontro é mais sem subterfúgios.

Íamos andando lado a lado. Meu pai se deteve para riscar o fósforo. Em sua mão côncava, acendeu uma estrela. Baixei meu rosto e me senti inundada pela flama, espécie de infernozinho particular da noite. Não fora assim sempre? Ele, dono da luz, sempre partindo, sempre se desenhando num horizonte, que se renovava em minha imaginação e me era vedado. Eu, na casa fechada, recriando-o, recebendo, à distância, a luz que ele emanava. Reconstituía suas grandes passadas, sua voz que fazia vibrar os cristais da étagère. Creio que vivi toda a minha vida numa espécie de plataforma de estação, à espera de transitórios viajantes... Agora, caminhava na madrugada ao lado do meu pai. Era São Paulo em torno e era a neblina. 
- Pena que haja cerração. Se o céu estivesse limpo, você me mostraria Betelgeuse; eu seria dona de constelações, de longínquas ilhas de luz. No terraço da fazenda, certa vez, enquanto me falava em Wells, em Flammarion, eu olhei seus olhos e eles estavam tão cheios de estrelas, que fiquei deslumbrada. Outro dia, disse a alguém que você nunca fora um pai de chinelas e de cadeira de balanço, e logo me senti plena de culpa. Não é muito melhor ter possuído um pai que era "o homem que andava na rua", espécie de marinheiro, para mim embarcado na nau de todas as aventuras e ainda carregando astros nos olhos?

Meu pai sorriu tenuamente, a distanciar-se como sempre foi de seu destino. A garoa do tempo, do sono, da vida e da morte, o foi colhendo e apagando. Sozinha no leito, ganhando lucidez, comecei a procurá-lo em minha carne, para lá de mim mesma, na aurora de meu ser que ainda não era... 


\section{A viagem e o beijo}

Já caminhei algo pelo mundo. Já transpus espaços largos em navio e avião. Andei por "Oropa, França e Bahia" e mergulhei até naquele Oriente Médio onde devem estar a lâmpada de Aladim e a cruz de Cristo. Foram incursões em territórios e almas, povoadas de mergulhos em sensibilidades diversas. Houve a moça drusa da montanha libanesa, a carregar seu cântaro, envolta em seus véus, parelha a uma remota estátua; e houve a muçulmana da gruta da Natividade; houve o mediterrâneo, a baía de Yune, os ciprestes, as oliveiras, o falar diverso e gutural... Entretanto, lembro-me hoje de outra viagem, que me parece muito mais longa que todas essas, e num território grande e pleno de mistérios. Não acredito que jamais viaje tanto em profundidade, extensão e tempo, mesmo que atravesse todos os meridianos e siga a rosa-dos-ventos de todas as estradas do mundo. Teria ano e meio, e uma visão de baixo para cima fazia que as pernas dos homens fossem altas como mastros, os trincos das portas inalcançáveis, os rostos perdidos em brumas de distâncias... Abriram-me uma porta, empurraram-me ao lado da irmã maior. Em torno, havia uma aura expectante de tragédia, e isso eu jamais esquecerei. Era como se me houvesse tornado uma periclitante ilhazinha, que o terrível mar ameaçasse de cobrir. A caminhada teria de ser até o fundo do quarto claro, com uma cama onde jazia uma jovem mulher de cabelos desfeitos nas alvuras dos travesseiros, e ela própria toda desfeita, como uma pobre rosa por demais desabrochada, no momento exato em que vai deixar cair toda as suas pétalas. Eu caminhava, medrosa de nunca chegar. Era possível haver na terra tal distância? Cada passo era um esforço, como se o piso se adensasse para me reter os pés. Em torno, pessoas soluçavam sobre mim:

- Coitadinha! 
Imaginam o que seja caminhar assim entre fileiras de pessoas que se magoam por nosso próprio desvalimento? E ter ano e meio de vida e já a idéia da hostilidade e da dureza do mundo? Mandavam-me caminhar, e eu caminhava fora e dentro de mim mesma.Caminhei um século, um continente, um mundo. A figura ao fundo do quarto era um altar em que se processava uma liturgia que se tornou depois em minha religião. Ao tocá-la após a caminhada sem fim, não recebi a hóstia, mas o aviso:

- Beije sua mãe na testa!

Fui levantada por braços poderosos, meu rosto roçou o rosto da mulher agonizante, os soluços de todos os lados davam-me a idéia de uma extrema e inenarrável desgraça. Depois, foi o retorno até a porta, o jardim, os dias, as flores, as mesas, as comidas, os brinquedos, as doçuras. Mas a caminhada na infância tão remota, para aquela despedida estendeu-se-me vida afora. Foi a viagem mais longa. Ao voltar, seria um navio largando para sempre o porto. Terá consciência o naviofantasma, que deixa assim uma angra, dos vendavais que o esperam, e, sobretudo, da impossibilidade de jamais encontrar amarras que o segurem na bonança e na paz? Não sei. Tinha um ano e meio quando beijei minha jovem mãe agonizante, e no fundo do coração era o medo e as trevas. 


\section{O príncipe Sisido}

Ele me ensinou as flores, as folhas, os arbustos, as manhãs, as tardes, os ventos e, sobretudo, o jardim. Antes dele, havia as salas altas de piso encerado, a cadeirinha dourada em forma de harpa, o piano onde minha irmã cantava o Reviens, veux-tu e outra irmã acordava para o romântico das sonatas. Lá fora, havia um vago mundo vegetal que me encantava. Foi ele que estabeleceu o primeiro nexo desse mundo com a criança que eu era.

- Venha, Helena, vamos colher flores!

E eu partia para o demorado encantamento, levada pelo japonês. Era o jardim com relvados em declive, na rua Maranhão. Sisido era copeiro. No Jardim da Infância, D. Mary Buarque talvez o catalogasse dentro da raça amarela. Contudo, jamais vi alguém tão alvo de pele, os cabelos negros e lisos, um rosado sadio nas faces. Era pequeno e elegante e, quando apresentava a bandeja de prata, parecia um príncipe entregando suas armas.

Um príncipe... Depois, a criadagem fez dele uma espécie de mito. Quando se foi, a cozinheira Custódia falou-me de gente fidalga que o procurara ao portão, afirmando o azul de seu sangue. Por que voltas dos fados fora imigrar para o nosso país? A nossa conversa abrangia muitas coisas, menos a sua pessoa. Através das flores que me fazia colher e ensinava a amar, impregnava-me de sua poética filosofia:

- Helena vai fazer um ramo... mas a rosa branca e grande é a lua. Então, a rosa branca fica mais baixa que a rosa vermelha, que é o sol. O sol é o Pai. Está mais alto que a Mãe. No ramo e na casa e no céu, o Pai e o sol estão mais alto...

Hoje penso que, se nesses momentos atentasse para suas longas mãos, veria partir delas flechas de luz, a exemplo do que se vê na imagem dos bem-aventurados. 
Era uma espécie de Francisco de Assis nipão, sem tonsuras, mas todo atento à voz dos pássaros, ao passar do vento nas touceiras dos bambus, ao jeito peculiar que tinha o sol de inverno de filtrar sua luz pela folhagem do jardim.

Deixou-nos mais tarde para ser chofer. Antes de partir, deu-me um cofrezinho de Charão, com flores e pássaros misturados, que talvez contivesse uma daquelas suas filosóficas mensagens.

Passaram-se os dias e, certa manhã, comunicaram-nos que Sisido fora recolhido, muito mal, a uma enfermaria da Santa Casa. Meu tio foi visitá-lo e viu que estava em seus últimos dias. Ao lhe indagar o que desejava, pediu-lhe que lhe trouxesse flores e uma escova de dentes (sua bela dentadura alva era a única vaidade de seu corpo).

Desci ao jardim, fiz um ramo com todas as figuras preconizadas, Deus, o Pai, a Mãe. Foram suas flores funerárias.Contaram-me que ele mergulhou, longamente e para sempre o rosto nesse pequeno jardim olente, que sua amiga Helena lhe fizera. Ali, também, imergiu para o insondável lago do lado de lá, onde nenúfares deviam boiar, criando-lhe um paraíso eterno. Nele não faltariam as touceiras de bambus, os ventos amenos da tarde... Quando o afastaram de meu ramo, estava morto. Docemente morrera, como falava, como vivia. Na mais pura das belezas.

Com a cidade toda cheia dessa brava gente que imigrou para lá vão cinqüenta anos, penso em meu amigo Sisido. Na verdade, depois que vieram para cá os japoneses, nós amamos um pouco mais, talvez, a terra marrom que Deus nos deu e toda a vegetação que dela podemos fazer brotar... Eles ensinaram muito do mundo mágico das plantas aos tristes homens urbanos, e fizeram de nossas caboclas goiabas pequenas luas impressionistas. 


\section{Geografia da morte}

Não sei em que pé andam as discussões em torno da cremação de cadáveres. Faz algum tempo, Câmara tomou conhecimento do problema e a dúvida surgiu: crema ou não crema? A cidade dos vivos cresce e, obviamente, prejudica a dos mortos, e estes impedem o trânsito... Leio em manchetes de vespertino: "Teme-se morrer na Capital: nos cemitérios não há vagas". Se viver é difícil em São Paulo, morrer não é menos. Há até câmbio negro de campas, e todo um escuso negócio a florescer junto às tumbas, como as boninas do poetas ligados às metafísicas indagações do "se eu morresse amanhã?".

Os cemitérios, no Brasil, a princípio eram coisas pequenas, tanto que podiam caber no recesso das igrejas: depois, veio febre amarela, e cólera, e os corpos mortos tiveram que transbordar desses recintos sagrados, e a cerimônia do enterramento de certo modo profanou-se. Este foi o primeiro golpe que a Morte padeceu, entre nós, no seu caráter de coisa transcendente, sobrenatural, fora da vida.

Com essa profanação da Morte, e as dificuldades cada vez maiores da vida, pensou-se, então, na cremação. Em câmaras altas, e não altas, discutiu-se o direito de o corpo ser queimado, é claro que depois de a alma haver abandonado o dito, e não antes, pois que aí teríamos um "complexo de Joana D’Arc", de que mulatas apaixonadas dos morros, ateando fogo às vestes, têm dado sucessivas reproduções. É óbvio que a incineração tem, antes de mais nada, indiscutível alcance estético. E não é preciso ser poeta para concluir-se que mais vale arder que apodrecer. Melhor ser cinza, obtida mais ou menos sinteticamente, à custa de fogo purificador, que esperar pelo trabalho meticuloso dos vermes sobre aquilo que foi corpo, mas agora é apenas inspiração de Baudelaire, vil carniça, charogne desalentada. 
Discussões travadas tiveram, de um lado, inclusive autoridades ilustres de nossa Igreja. Ao que parece, esta seria contrária, em virtude do mandamento divino que impõe à alma o dever de procurar seu esqueleto para o dia do Juízo Final, e conseqüentemente ressurreição dos mortos. Mas, em minha ignorância, suponho que todos aqueles simbólicos preceitos bíblicos sofrem interpretações nem sempre exatas. Então, quem morre por acidente, em incêndio, não encontra morada para o espírito? E Santa Joana? E tantos e tantos outros mártires católicos?

Antigamente, o que havia era o Romantismo, era a atitude romântica perante a vida e as suas conseqüências. E, nesse sentido, a Morte era cantada. Agora, outros fatores aparecem: o crescimento das metrópoles dos vivos, e também o preço exorbitante dos terrenos, quer sejam eles para verticais ou eternos horizontais. Para a concentração dos inquietos ou dos quietos. Não só o chão está caro, mas o granito, mármore, toda a matéria-prima para a construção da casa da morada última. Daqui a pouco não será de estranhar que surjam anúncios de vastos condomínios com pequenas entradas e, depois, módicas prestações para uma residência que será de séculos...

Devido à cidade dos vivos estar de tal modo congestionada, já se falou até em cemitério subterrâneo. O projetista imaginou, em cima, uma grande garagem. Quem lá guardasse o seu Cadillac, estaria em face, ou por outra, por cima de considerações velhas como o mundo, tal seja "a morte tudo iguala". E, nesse caso, pedestre ou motorizado. Enfim, a tradição de passar a considerar a morte uma coisa sem nenhum halo sobrenatural, dá um passo à frente. Estamos longe, como se vê, do sacratismo enterramento nas igrejas. A vida vai adquirindo a grande familiaridade com a Morte, que sempre devia ter. É como a evolução do comportamento entre pais e filhos. Na sociedade patriarcal, uns distanciavam-se. Agora se misturam. Se a Morte é mãe da 
vida, se vida e morte estão sempre emaranhadas, se nossos mortos estão na raiz de nossas unhas, e nos forram o espírito, e prosseguem em nossos gestos, por que não tê-los, ou subterraneamente sob nossos pés, na cidade, ou em suas pequenas gavetas de cinzas? Dormem no fundo de nós, e não têm importância onde seja, ou de que modo, o seu dormir geográfico. 


\section{ANEXO B}

\section{Uma Carniça (Charles Baudelaire)}

Lembra-te, meu amor, do objeto que encontramos

Numa bela manhã radiante:

$\mathrm{Na}$ curva de um atalho, entre calhaus e ramos,

Uma carniça repugnante.

As pernas para cima, qual mulher lasciva,

A transpirar miasmas e humores,

Eis que as abria desleixada e repulsiva,

$\mathrm{O}$ ventre prenhe de livores.

Ardia o sol naquela pútrida torpeza,

Como a cozê-la em rubra pira

E para ao cêntuplo volver à Natureza

Tudo o que ali ela reunira.

E o céu olhava do alto a esplêndida carcaça

Como uma flor a se entreabrir.

O fedor era tal que sobre a relva escassa

Chegaste quase a sucumbir.

Zumbiam moscas sobre o ventre e, em alvoroço,

Dali saíam negros bandos

De larvas, a escorrer como um líquido grosso

Por entre esses trapos nefandos.

E tudo isso ia e vinha, ao modo de uma vaga,

Ou esguichava a borbulhar,

Como se o corpo, a estremecer de forma vaga, 
Vivesse a se multiplicar.

E esse mundo emitia uma bulha esquisita, Como vento ou água corrente,

Ou grãos que em rítmica cadência alguém agita E à joeira deita novamente.

As formas fluíam como um sonho além da vista, Um frouxo esboço em agonia, Sobre a tela esquecida, e que conclui o artista Apenas de memória um dia.

Por trás das rochas irrequieta, uma cadela Em nós fixava o olho zangado, Aguardando o momento de reaver àquela Náusea carniça o seu bocado.

- Pois hás de ser como essa infâmia apodrecida, Essa medonha corrupção, Estrela de meus olhos, sol de minha vida, Tu, meu anjo e minha paixão!

Sim! tal serás um dia, ó deusa da beleza, Após a benção derradeira, Quando, sob a erva e as florações da natureza, Tornares afinal à poeira.

Então, querida, dize à carne que se arruína, Ao verme que te beija o rosto, Que eu preservei a forma e a substância divina De meu amor já decomposto! 
9 ANEXO C

Neste anexo constam as crônicas pertencentes à obra Sombra Azul e Carneiro Branco de Helena Silveira que possuem como temática a morte. 